\title{
Enantioselective $\alpha$-Arylation of Primary Alcohols under Sequential One-Pot Catalysis
}

\author{
Bruno Lainer, Dawid Lichosyt,* Maiia Aleksandrova, and Paweł Dydio* \\ University of Strasbourg, CNRS, ISIS UMR 7006, 8 allée Gaspard Monge, 67000 Strasbourg, France
}

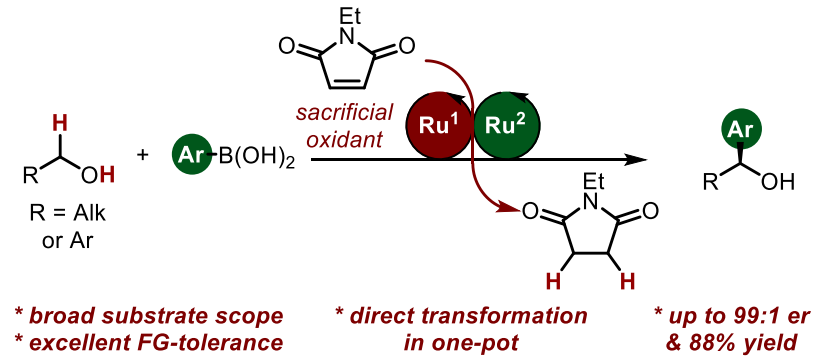

ABSTRACT: Secondary benzylic alcohols (SBAs) and diarylmethanols (DAMs) are common structural motifs of biologically active and medicinally relevant compounds. Here we report their enantioselective synthesis by $\alpha$-arylation of primary aliphatic and benzylic alcohols under sequential catalysis integrating a Ru-catalyzed hydrogen-transfer oxidation and a Ru-catalyzed nucleophilic addition. The method is applicable to various alcohols and aryl nucleophiles tolerating a range of functional groups, including secondary alcohols, ketones, alkenes, esters, $\mathrm{NH}$-amides, tertiary amines, aryl halides, and heterocycles.

Secondary benzylic alcohols (SBAs) and diarylmethanols (DA Ms) constitute valuable synthetic intermediates and prevalent structural motifs of numerous natural products and bioactive compounds. ${ }^{1,2}$ Therefore, protocols for their stereoselective synthesis from various accessible starting materials have attracted much attention over the years. Common approaches include potent asymmetric (transfer) hydrogenation of ketones ${ }^{1,3,4}$ or 1,2-addition of aryl nucleophiles to aldehydes, ${ }^{5,6}$ particularly useful for fine-chemical synthesis when such starting materials are available and do not require additional synthetic steps.

Because aliphatic alcohols represent a class of abundant starting materials, increasing attention has been devoted to developing methods for their valorization through selective $\mathrm{C}-\mathrm{H}$ bond functionalization. ${ }^{7-9}$ In the context of SBAs, an elegant strategy for the enantioselective alkylation of $\alpha-\mathrm{C}-\mathrm{H}$ bonds of primary benzylic alcohols with unsaturated hydrocarbons (e.g., dienes, enynes) was devised by Krische and co-workers (Scheme 1a). ${ }^{10,11}$ The methods of the arylation of $\alpha-\mathrm{C}-\mathrm{H}$ bonds of aliphatic alcohols in the Minisci-type reactions were also established. ${ }^{12-17}$ (Scheme 1b). Unfortunately, these methods lead to racemic products, leaving the enantioselective $\alpha-\mathrm{C}-\mathrm{H}$ arylation of alcohols unexplored.

We have recently reported an enantioselective synthesis of SBAs from unsaturated alcohols and aryl boronic acids under sequential catalysis (Scheme 1c). ${ }^{18}$ The one-pot sequence of an Ir-catalyzed isomerization of the starting material and a Ru-catalyzed nucleophilic addition of an aryl boronic acid to the aldehyde intermediate provided a convenient synthetic method with a broad scope and functional group tolerance. 
a. asymmetric $\alpha$-alkylation of benzylic alcohols (Krische)

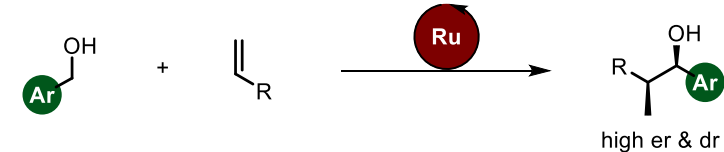

b. racemic $\alpha$-arylation of alcohols (Minisci-type reactions)

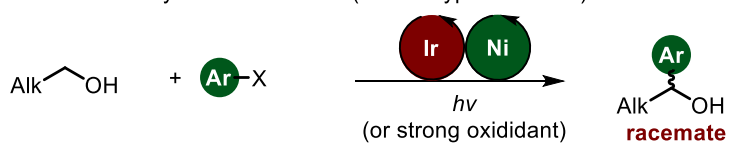

c. asymmetric isomerisation-addition of alkenols (our previous work)

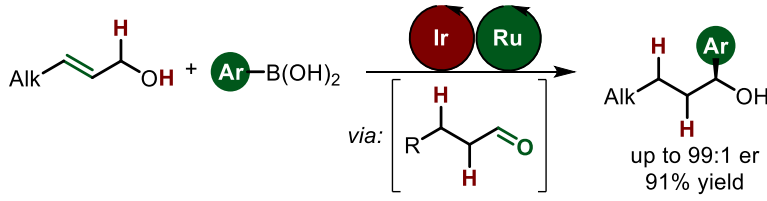

d. asymmetric $\alpha$-arylation of primary alcohols (this work)

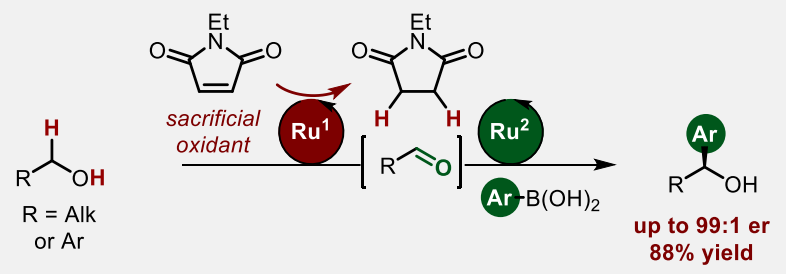

Intrigued by the prospect of employing a multicatalytic sequential approach to the enantioselective synthesis of SBAs from readily available primary alcohols, we considered utilizing an intermolecular hydrogen-transfer ${ }^{19}$ between the starting material and a sacrificial acceptor (in place of the intramolecular isomerization step) followed with a stereoselective 1,2-addition step (Scheme 1d). Attractively, hydrogen transfer catalysis enables selective oxidation of one out of multiple alcohol moieties in the presence of other functional groups, rendering its utility in the late-stage modifications of complex molecules. ${ }^{19,20}$

Here we report, established by the above design, a dual-catalytic method for the enantioselective $\alpha$-arylation of primary aliphatic or benzylic alcohols with aryl boronic acids as nucleophiles. The protocol integrates a Ru-catalyzed hydrogen transfer oxidation with an enantioselective Ru-catalyzed 1,2-addition of an aryl nucleophile in a one-pot fashion to form either secondary benzylic alcohols or chiral diarylmethanols in up to 99:1 enantiomeric ratio (er) and 88\% yields (Scheme 1d).

The development of a multicatalytic system that executes the envisioned sequential transformation required careful balancing of the conditions to ensure compatibility between the catalysts, reagents, and intermediates of the consecutive steps. ${ }^{21-25}$ Special attention must be paid to the selection of the catalysts, considering that any cross-reactivity or any ligand scrambling is likely not only to decrease the required activity but also be detrimental for the overall stereoselectivity. ${ }^{26,27}$ The Ru-catalyst containing me-bipam, a chiral phosphoramidite ligand developed by Yamamoto and Miyaura, proved previously both highly enantioselective in the arylation of aldehydes ${ }^{28,29}$ and compatible with a series of phosphine-Ru complexes, ${ }^{18}$ which represent prospective hydrogen-transfer catalysts. ${ }^{19,20}$ Therefore, Ru-complex bearing me-bipam was selected as a catalyst of choice for the 1,2-addition step, and the main efforts for the method development were focused on identifying a phosphine-Ru-based hydrogen-transfer catalyst and a sacrificial hydrogen acceptor (HA). While typically used in its large excess, ${ }^{19,20}$ a suitable hydrogen acceptor would be preferably used in stoichiometric amounts, preventing secondary oxidation reactions or any cross-reactivity in the subsequent 1,2-addition step. 
Extensive experimentation of the model reaction of 1-hexanol 1a with phenylboronic acid 2a identified that hydrogen-transfer between the alcohol and N-ethylmaleimide HA-1, used as a sacrificial hydrogen acceptor (1.1 equiv), in the presence of the Rucomplex bearing rac-binap (Ru-1) that is followed with the 1,2-addition of the aryl nucleophile in the presence of the Ru-complex bearing (S,S)-me-bipam (Ru-2) furnished product 3aa in 96:4 er (S:R) and 88\% yield (80\% isolated yield; Table 1, entry 1). The reaction mixture contained $10 \%$ of unreacted alcohol 1a, while all aldehyde intermediate was converted, indicating the excellent efficiency of Ru-2 in the second step. Control experiments confirmed the role and the required reactivity of both complexes. First, we observed that the stereoselectivity of the product is not influenced by $\mathbf{R u - 1}$ (entry 2), and the complex with a racemic mixture of binap can be used. Further, no product was formed when Ru-2 was omitted (Table S1, entry 14), indicating that Ru-1 is completely inactive in the second step of the reaction. Similarly, no product was formed when Ru-1 was omitted and Ru-2 was employed in both steps, indicating that $\mathbf{R u - 2}$ is completely inactive in the oxidation step, even for benzylic alcohols that are typically easily dehydrogenated (Table S1, entry 15). In turn, reactions in the presence of other ligands in place of binap, such as xantphos, dpephos or dppf, occurred in substantially lower yields $(\leq 39 \%)$, albeit high enantioselectivity was maintained (entries 3-5), underscoring the robustness of catalyst Ru-2. Noteworthy, the presence of sodium acetate in the $1: 1$ ratio per Ru-site is key for the hydrogen transfer activity of Ru-1. No reaction or substantially decreased activity was observed in its absence or when the amount was 5-fold increased (entries 6-7). Similarly, no reaction was observed when $\mathbf{R u - 3}$, an analogue of Ru-1 bearing acetate ligands in place of chloride anions, was used; but the reactivity of $\mathbf{R u - 3}$ was partially recovered in the presence of additives bearing chloride anions (entries 8-9). These observations suggest that a mixed-ligand Ru-complex might be the active species $;{ }^{30,31}$ however, further studies are required to verify this hypothesis. N-Ethylmaleimide HA-1 proved to be by far the most efficient as a sacrificial hydrogen acceptor among tested. Up to $33 \%$ of 3aa was formed when diethyl maleate or fumarate were used instead, and no reactions occurred with norbornadiene, ethyl methacrylate or acetone (entries 11-15). The lack of inert atmosphere, other solvents or lower loadings of the catalysts result in lower yields of the reaction (Table S1).

The hydrogen-transfer activity of Ru-1 was found to be selective toward primary aliphatic alcohols over secondary alcohols, creating the attractive possibility for $\alpha$-functionalization of primary alcohol moieties in the presence of other alcohol functions. Specifically, the competition experiments between linear 1a and a series of branched aliphatic alcohols 1b-e revealed 7:1 kinetic selectivity for the reaction of primary $\mathbf{1 a}$ over ( $\alpha$-branched) secondary $\mathbf{1 b}$ and nearly no selectivity over other primary alcohols, $\beta$-branched $\mathbf{1 c}$ $\mathbf{d}$ or $\gamma$-branched 1e (Scheme 2). In sharp contrast, primary benzylic alcohol $\mathbf{1 f}$ reacted selectively over primary aliphatic alcohol 1a (6:1 ratio), revealing the highest reactivity of $\mathbf{1 f}$ among alcohols $\mathbf{1 a - 1 f}$.

The established dual $\mathrm{Ru}-/ \mathrm{Ru}$-catalytic protocol is easily scalable, broadly applicable, and tolerant to many common functional groups (Scheme 3). A range of primary aliphatic alcohols was converted to SBAs with 93:7-98:2 er and 44-82\% yield of isolated material. Reactions for alcohol 1a on standard $(0.25 \mathrm{mmol})$ and larger $(1.75 \mathrm{mmol})$ scales furnished product 3aa with the same selectivity (96:4 er) and similar yields (80-84\%). Besides $\mathbf{1 a}$ and unsaturated $\mathbf{1 g}$ aliphatic alcohols, $\beta, \beta$-disubstituted alcohol $\mathbf{1 h}$ as well as ethanol $\beta$-substituted with a cyclohexyl group $\mathbf{1 i}$ or an aryl group $\mathbf{1 j}$ reacted to form the target products. Starting materials bearing common functional groups, such as a carboxylic ester $\mathbf{1 k}$, a tertiary amide $\mathbf{1}$, or an NH-containing amide $\mathbf{1 m}$ are tolerated. Alcohols containing free NH-amines or terminal alkynes as well as (homo)allylic alcohols are not compatible (Figure S2), due to either side-reactions or no conversion in the presence of Ru-1. However, the reaction for alcohol bearing N-phthalimide-protected amine 1n furnished the target product. Most noteworthy are reactions of primary alcohols bearing a ketone $\mathbf{1 0}$ or a secondary alcohol 10 functions, which were not hampered by either competitive 1,2-addition or oxidation but formed the target products in 58-64\% yields and with 97:3 stereoselectivity for the formation of the new stereogenic center (racemic diol 1p was used, hence product $\mathbf{3 p a}$ was formed as a 1:1 mixture of diastereomers with 97:3 er). 


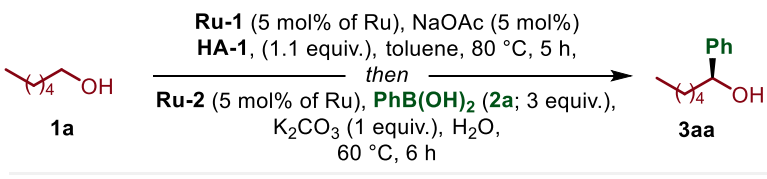

Ru-1: $\left[\mathrm{Ru} \text { (cymene) } \mathrm{Cl}_{2}\right]_{2} /$ rac-binap, Ru-2: $\left[\mathrm{Ru}(\text { cymene }) \mathrm{Cl}_{2}\right]_{2} /(S, S)$-me-bipam Ru-3: $\left[\mathrm{Ru}(\mathrm{cymene})(\mathrm{OAc})_{2}\right] /$ rac-binap

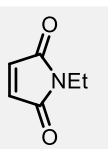

HA-1

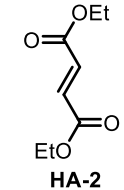

11

HA-4

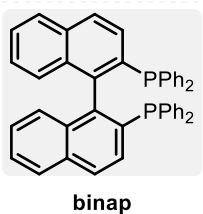

binap<smiles>C=CC(=O)C(C)C</smiles>

HA-5

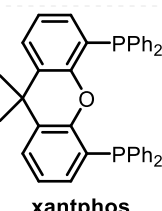<smiles>CCOC(=O)/C=C\C(=O)OCC</smiles>

HA-3<smiles>CC(C)=O</smiles>

HA-6

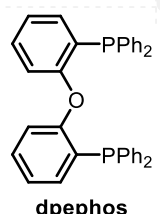

variations from the standard cond.

none

yield $(\%) \quad$ er

$88(80)^{\mathrm{b}} \quad 96: 4$

(R)- or (S)-binap used

90-91 96:4

xantphos instead of binap

dpephos instead of binap

5

$3996: 4$

dppf instead of binap

no $\mathrm{NaOAc}$

$25 \mathrm{~mol} \% \mathrm{NaOAc}$

Ru-3 instead of Ru-1

Ru-3 + 10 mol\% TBACl (no Ru-1)

no HA-1

HA-2 instead of HA-1

HA-3 instead of HA-1

HA-4 instead of HA-1

HA-5 instead of HA-1

HA-6 instead of HA-1

$20 \quad 94: 6$

$<2 \quad-$

$20-$

$<2 \quad-$

$50 \quad 96: 4$

$<2 \quad-$

$33 \quad 96: 4$

$32 \quad 97: 3$

$<2 \quad-$

$<2 \quad-$

$<2 \quad-$

a Standard conditions: 1a (0.25 mmol), HA-1 (1.1 equiv), Ru-1 (5 mol\% of Ru-site $-2.5 \mathrm{~mol} \%$ of Ru-dimer), NaOAc (5 mol\%), toluene (1 $\mathrm{mL})$, stirred for $5 \mathrm{~h}$ at $80{ }^{\circ} \mathrm{C}-(\operatorname{step} 1)$; then $\mathbf{2 a}$ (3 equiv), $\mathrm{K}_{2} \mathrm{CO}_{3}$ (1 equiv) in $\mathrm{H}_{2} \mathrm{O}(0.15 \mathrm{~mL}),(S, S)-\mathbf{R u}-\mathbf{2}(5 \mathrm{~mol} \%$ of Ru-site - $2.5 \mathrm{~mol} \%$ of Ru-dimer) in toluene ( $1 \mathrm{~mL})$ were added and stirred for $6 \mathrm{~h}$ at $80{ }^{\circ} \mathrm{C}$ - (step 2); yields by ${ }^{1} \mathrm{H}$ NMR analysis with an internal standard; enantiomeric ratio (er; $S: R$ ) determined by SFC analysis; for details, see the SI. ${ }^{\text {b }}$ Yield of isolated material. 
Scheme 2. Selectivity of the hydrogen transfer from varied alcohols by Ru-2 - competition experiments a
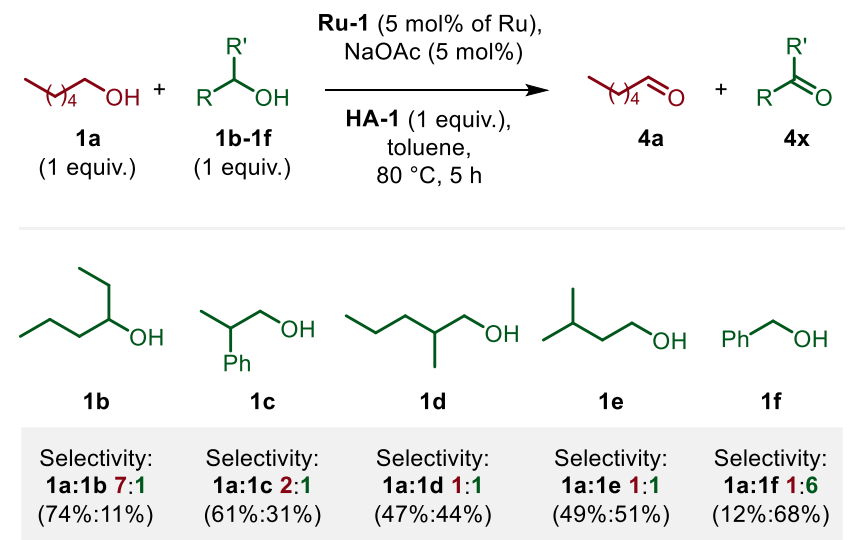

${ }^{\text {a }}$ Reactions under the standard conditions of step 1, see Table 1; conversions were determined by GC-FID analysis with dodecane as an internal standard; for details, see the SI.

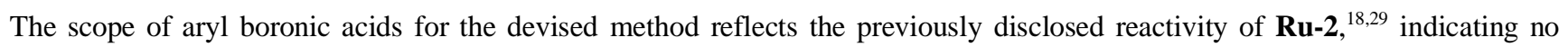
noticeable effect of Ru-1 catalyst on the 1,2-addition step. Specifically, a range of aryl boronic acid derivatives bearing either electron-donating or electron-withdrawing substituents in the para- or meta-position of the aryl ring reacted to deliver the target products with 91:9-97:3 er and 54-81\% yield of isolated material. Noteworthy are previously undisclosed examples of benzofuran $\mathbf{2 h}$ and triphenylamine derivatives $\mathbf{2} \mathbf{i}$ that reacted to form the products with 96:4-91:9 er and 59-80\% yields. Reactions for aryl boronic acids bearing either a strongly electron-withdrawing group or steric hindrance in the ortho-position, such as $\mathbf{2 d}$ and $\mathbf{2 f}$, respectively, furnished the products in modest yields, indicating the limitations of the protocol imposed by the inherent limitations of $\mathbf{R u}-\mathbf{2} ;{ }^{18}$ no additional limitations related to the presence of Ru-1 were encountered in the 1,2-additon step.

Lastly, intrigued by the high reactivity of benzylic alcohol $\mathbf{1 f}$ in hydrogen transfer reactivity mediated by $\mathbf{R u - 2}$, we evaluated the established protocol toward enantioselective $\alpha$-arylation of benzylic alcohols to form diarylmethanols (DAMs), which are known to exhibit potent biological and medicinal properties. ${ }^{2}$ Pleasingly, $\mathbf{1 f}$ reacted with electron-rich $\mathbf{2} \mathbf{j}$ or electron-deficient $\mathbf{2 k}$ aryl boronic acids under standard conditions to form chiral DAMs with over 97:3 er and 66-78\% yields of isolated material. Further, electrondeficient benzyl alcohols 1q-1r and electron-rich 3-furanmethanol 1s reacted with $\mathbf{2 a}$ to form the target products with $>96: 4$ er and $27-70 \%$ yield of isolated material.

In conclusion, the disclosed dual catalytic protocol enables the formal enantioselective arylation of $\alpha-\mathrm{C}-\mathrm{H}$ bond of primary aliphatic and benzylic alcohols with varied aryl boronic acids. Importantly, the method tolerates starting materials and nucleophilic reagents bearing a range of common functional groups, including secondary alcohols and ketones. The one-pot strategy offers advantages over tedious and wasteful stepwise approaches, ${ }^{32-35}$ especially for sequences occurring through the aldehyde intermediates that are often prone to undergo side reactions. In a greater perspective, the study demonstrates that sequential catalysis complements current strategies for the functionalization of strong $\mathrm{C}-\mathrm{H}$ bonds that require enforcing conditions with limited applicability in finechemical synthesis or those that are burdened with limited control of chemo-, regio- or stereoselectivity. 


$$
\begin{aligned}
& \text { Ru-1 (5 mol\% of Ru), NaOAc ( } 5 \mathrm{~mol} \% \text { ) } \\
& \text { HA-1, (1.1 equiv), toluene, } 80^{\circ} \mathrm{C}, 5 \mathrm{~h} \text {, } \\
& \mathrm{R} \widehat{\mathrm{OH}}
\end{aligned}
$$

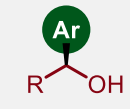

Aliphatic alcohols<smiles>CCCCCC(O)Pc1ccccc1</smiles>

3aa: $80 \%$, er $96: 4$ scale-up: ${ }^{\text {b }} 84 \%$, er $96: 4$<smiles>CC(C)OC(=O)CCCCC(O)c1ccccc1</smiles>

3ka: $66 \%$, er $95: 5$<smiles>C=CCCCC(O)c1ccccc1</smiles>

3ga: $79 \%$, er $98: 2$<smiles>CC(C)C(O)c1ccccc1</smiles>

3ha: $80 \%$, er $96: 4$<smiles>COc1ccc(CC(O)c2ccccc2)cc1</smiles>

3ja: $44 \%$, er $93: 7$

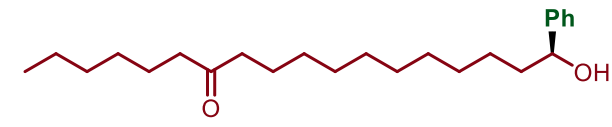

3oa:e $58 \%$, er $97: 3$<smiles>O=C(CCCCC(O)c1ccccc1)NC1CCCCC1</smiles>

$3 \mathrm{ma}:{ }^{\mathrm{c}} 55 \%$, er $96: 4$<smiles>O=C1c2ccccc2C(=O)N1CCCCC(O)c1ccccc1</smiles>

3na: ${ }^{c} 49 \%$, er $97: 3$<smiles>CCCCCC[C@H](O)CCCCCCCCCCC(O)c1ccccc1</smiles>

3pa: $64 \%$, er $97: 3(\mathrm{dr} 1: 1)^{f}$

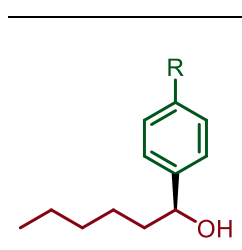

3ab: ${ }^{9} \mathrm{R}=\mathrm{Ph}: 54 \%$, er $92: 8$ 3ac: $R=F: 77 \%$, er $96: 4$ 3ad: ${ }^{\mathrm{h}} \mathrm{R}=\mathrm{CF}_{3}: 22 \%$<smiles>COc1ccc([C@@H](O)c2ccccc2)cc1</smiles>

3fj: $78 \%$, er $99: 1$

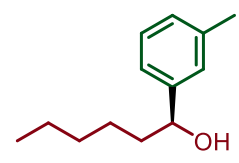

3ae: $67 \%$, er $91: 9$

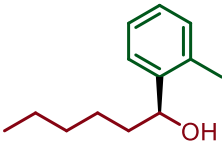

3af: ${ }^{\text {h }}<5 \%$

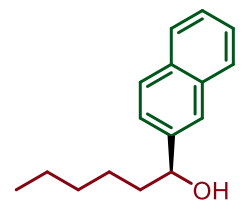

3ag: $81 \%$, er $97: 3$

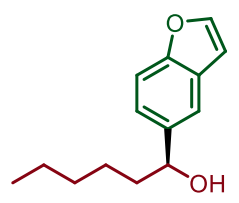

3ah: $59 \%$, er $96: 4$

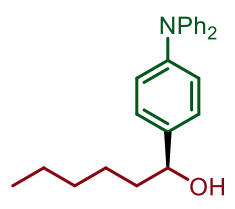

3ai: $80 \%$, er $91: 9$

Benzylic alcohols<smiles>O[C@H](c1ccccc1)c1cccc(Cl)c1</smiles>

3fk: $66 \%$, er $97: 3$<smiles>O[C@H](c1ccccc1)c1cc(C(F)(F)F)cc(C(F)(F)F)c1</smiles>

3qa: $42 \%$. er $96: 4$<smiles>OC(c1ccccc1)c1ccc(Br)cc1</smiles>

3ra: $70 \%$, er $97: 3$

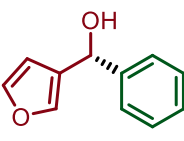

3sa: $27 \%$, er $99: 1$

${ }^{a}$ Reaction conditions: see Table 1; yields correspond to the isolated material; for details, see the SI. ${ }^{\mathrm{b}}$ reaction conducted on a 1.75 mmol scale. ${ }^{\mathrm{c}}$ double loading of Ru-2 (10 mol\% of Ru). ${ }^{\mathrm{d}}$ alcohol 1 (0.20 mmol), 2 (0.60 mmol). ${ }^{\mathrm{e}}$ alcohol $1(0.13 \mathrm{mmol}), 2(0.39 \mathrm{mmol}) .{ }^{\mathrm{f}} \mathrm{racemic}$ diol 10 was used as the starting material. ${ }^{\mathrm{g}} 90{ }^{\circ} \mathrm{C}$ in step $2 .{ }^{\mathrm{h}}$ Yield by ${ }^{1} \mathrm{H}$ NMR analysis using an internal standard. ${ }^{\mathrm{i}} 16 \mathrm{~h}$ in step 1.

\section{EXPERIMENTAL SECTION}

General Information. Unless stated otherwise, all reactions and manipulations were conducted on a laboratory bench or in a wellventilated fume hood in air with reagent grade solvents. Reactions under inert gas atmosphere were carried out in the oven-dried glassware in a nitrogen-filled glovebox or by standard Schlenk techniques under nitrogen. Unless noted otherwise, all reagents and solvents were purchased from commercial suppliers and used without further purification. $(S, S)$-BIPAM was prepared according to 
the literature procedure. ${ }^{36,37} \mathrm{Ru}(p$-cymene $)(\mathrm{OAc})_{2}$ was prepared according to the literature procedure. ${ }^{38}$ For experiments under inert gas atmosphere, dry solvents like dichloromethane (DCM), tetrahydrofuran (THF), toluene, hexane, and diethyl ether $\left(\mathrm{Et}_{2} \mathrm{O}\right)$ dioxane, acetonitrile, 1,4-xylene, were purchased from commercial suppliers and used as received. Water was degassed by purging with nitrogen for 30 min. Column chromatography was carried out with the aid of CombiFlash EZ Prep Chromatography System with integrated ELSD using the RediSep Rf (Gold) Silica Gel Disposable Flash columns. TLC visualization was carried out with ultraviolet light $\left(254 \mathrm{~nm}\right.$ ), followed by staining with a $1 \%$ aqueous $\mathrm{KMnO}_{4}$ solution. NMR spectra were acquired on the $400 \mathrm{MHz}$ or $500 \mathrm{MHz}$ Bruker instruments at the Institute of Science and Supramolecular Engineering (ISIS), University of Strasbourg, Strasbourg. NMR spectra were processed using the MestReNova 14.2 software. Chemical shifts are reported in parts per million (ppm) and referenced to residual solvent peaks or tetramethylsilane (TMS). Coupling constants are reported in hertz (Hz). SFC analysis was conducted using an Agilent SFC 1260 Infinity II instrument connected to an Agilent MSD XT mass spectrometry equipment. Chiral SFC separation was achieved using Chiralpak SFC (100 mm x 3 mm ID x $3 \mu \mathrm{m})$ columns. GC-FID analysis was obtained either on a Shimadzu GC2010 Plus instrument equipped with a SH-Rxi-5MS column ( $25 \mathrm{~m}$ x $0.20 \mathrm{~mm}$ ID x $0.33 \mu \mathrm{m}$ film) connected to a FID detector, or on a ThermoFisher TRACE 1300 instrument equipped with a HP-5 column ( $25 \mathrm{~m}$ x $0.20 \mathrm{~mm}$ ID x $0.33 \mu \mathrm{m}$ film) for achiral analysis or with an CP-Chiralsil- Dex CB column (30m x $0.25 \mathrm{~mm} \times 0.25 \mu \mathrm{m}$ film) for chiral analysis, connected to a FID detector. GC-MS analysis was obtained on a Shimadzu QP2020 (EI) instrument equipped with a SH-Rxi-5MS column (25 m x $0.20 \mathrm{~mm}$ ID x $0.33 \mu \mathrm{m}$ film. GC and NMR yields were calculated using 1,3,5-trimethoxybenzene or dodecane as the internal standards. GC yields were corrected for response factors for all compounds. Optical rotations were measured on a Perkin Elmer Precisely/Model-341 polarimeter operating at the sodium D line with a $100 \mathrm{~mm}$ path cell. Electrospray ionization high-resolution mass spectra (ESI-HRMS) were obtained on ThermoFisher Ultimate3000 with Scientific Vanquish Flex UHPLC with a ThermoFisher Orbitrap: Exactive Plus with Extend Mass Range: Source HESI II (at ISIS).

\section{Starting materials.}

Starting materials 1a-1j, 1q-1s were purchased from common chemical suppliers and used without further purification. Other starting materials were prepared and characterized as described below.

Isopropyl 6-hydroxyhexanoate (1/k): Compound $\mathbf{1 k}$ was prepared from caprolactone and isopropanol according to the literature procedure. ${ }^{9}$ The NMR data match those of the reported molecule. ${ }^{1}{ }^{1} \mathrm{H}$ NMR $(400 \mathrm{MHz}, \mathrm{CDCl} 3) \delta{ }^{1} \mathrm{H}$ NMR $\left(500 \mathrm{MHz}, \mathrm{CDCl}_{3}\right) \delta 4.94$ (hept, $J=6.3 \mathrm{~Hz}, 1 \mathrm{H}), 3.58(\mathrm{t}, J=6.5 \mathrm{~Hz}, 2 \mathrm{H}), 2.21(\mathrm{t}, J=7.5 \mathrm{~Hz}, 2 \mathrm{H}), 1.63-1.48(\mathrm{~m}, 4 \mathrm{H}), 1.43-1.24(\mathrm{~m}, 3 \mathrm{H}), 1.16(\mathrm{~d}, J=6.2$ $\mathrm{Hz}, 6 \mathrm{H})$.

$N$-cyclohexyl-6-hydroxyhexanamide (11): Compound $\mathbf{1 1}$ was prepared from cyclohexylamine and caprolactone according to the literature procedure. ${ }^{9}$ The NMR data match those of the reported molecule. ${ }^{1}{ }^{1} \mathrm{H}$ NMR $\left(500 \mathrm{MHz}, \mathrm{CDCl}_{3}\right) \delta 5.20(\mathrm{bs}, 1 \mathrm{H}), 3.76-3.64$ $(\mathrm{m}, 1 \mathrm{H}), 3.59(\mathrm{t}, J=6.5 \mathrm{~Hz}, 2 \mathrm{H}), 2.08(\mathrm{t}, J=7.5 \mathrm{~Hz}, 2 \mathrm{H}), 1.88-1.80(\mathrm{~m}, 2 \mathrm{H}), 1.68-1.47(\mathrm{~m}, 8 \mathrm{H}), 1.41-1.27(\mathrm{~m}, 4 \mathrm{H}), 1.14-0.94$ $(\mathrm{m}, 3 \mathrm{H})$.

6-Hydroxy-1-(piperidin-1-yl)hexan-1-one (1m): Compound $1 \mathbf{m}$ was prepared from piperidine and caprolactone according to the literature procedure. ${ }^{9}$ The NMR data match those of the reported molecule. ${ }^{9}{ }^{1} \mathrm{H}$ NMR $(400 \mathrm{MHz}, \mathrm{CDCl} 3) \delta 3.63-3.56(\mathrm{~m}, 2 \mathrm{H}), 3.51$ $-3.45(\mathrm{~m}, 2 \mathrm{H}), 3.35-3.29(\mathrm{~m}, 2 \mathrm{H}), 2.26(\mathrm{t}, J=7.5 \mathrm{~Hz}, 2 \mathrm{H}), 1.64-1.42(\mathrm{~m}, 11 \mathrm{H}), 1.40-1.30(\mathrm{~m}, 2 \mathrm{H})$.

rac-Octadecane-1,12-diol (1p): Compound $\mathbf{1 p}$ was prepared according to literature procedure from rac-12-hydroxystearic acid according to the literature procedure. ${ }^{9}$ The NMR data match those of the reported molecule. ${ }^{9}{ }^{1} \mathrm{H}$ NMR $\left(400 \mathrm{MHz}, \mathrm{CDCl}_{3}\right) \delta 3.65(\mathrm{t}$, $J=6.6 \mathrm{~Hz}, 2 \mathrm{H}), 3.62-3.56(\mathrm{~m}, 1 \mathrm{H}), 1.67-1.51(\mathrm{~m}, 2 \mathrm{H}), 1.51-1.20(\mathrm{~m}, 30 \mathrm{H}), 1.00-0.82(\mathrm{~m}, 3 \mathrm{H})$.

18-hydroxyoctadecan-7-one (1o): Compound 10 was prepared from $1 \mathbf{p}$ according to the literature procedure. ${ }^{9}$ The NMR data match those of the reported molecule. ${ }^{1}{ }^{\mathrm{H}} \mathrm{NMR}\left(500 \mathrm{MHz}, \mathrm{CDCl}_{3}\right) \delta 3.57(\mathrm{t}, J=6.7 \mathrm{~Hz}, 2 \mathrm{H}), 2.31(\mathrm{t}, J=7.4 \mathrm{~Hz}, 4 \mathrm{H}), 1.68-1.35(\mathrm{~m}, 9 \mathrm{H})$, $1.35-1.07$ (m, 18H), $0.94-0.66$ (m, 3H). 
2-(5-Hydroxypentyl)isoindoline-1,3-dione (1n): Compound 1n was prepared from phthalic anhydride and 5-aminopentan-1-ol according to the literature procedure. ${ }^{39}$ The NMR data match those of the reported molecule. ${ }^{39}{ }^{1} \mathrm{H} \mathrm{NMR}\left(400 \mathrm{MHz}, \mathrm{CDCl}_{3}\right) \delta 7.77(\mathrm{dd}$, $\mathrm{J}=5.4,3.1 \mathrm{~Hz}, 2 \mathrm{H}), 7.64(\mathrm{dd}, \mathrm{J}=5.5,3.1 \mathrm{~Hz}, 2 \mathrm{H}), 3.63(\mathrm{t}, \mathrm{J}=7.2 \mathrm{~Hz}, 2 \mathrm{H}), 3.57(\mathrm{t}, \mathrm{J}=6.5 \mathrm{~Hz}, 2 \mathrm{H}), 1.72-1.60(\mathrm{~m}, 2 \mathrm{H}), 1.60-1.50$ $(\mathrm{m}, 2 \mathrm{H}), 1.43-1.30(\mathrm{~m}, 3 \mathrm{H})$.

General Procedure for $\boldsymbol{\alpha}$-Arylation of Alcohols. In a nitrogen-filled glove box, a solution of $\mathbf{R u} \mathbf{- 1}$ and sodium acetate was prepared by allowing to $\operatorname{stir}\left[\mathrm{Ru}(p \text {-cymene }) \mathrm{Cl}_{2}\right]_{2}(0.025$ equiv, $0.0063 \mathrm{mmol}, 3.8 \mathrm{mg}), \mathrm{rac}$-binap $(0.05 \mathrm{equiv}, 0.013 \mathrm{mmol}, 7.8 \mathrm{mg})$, and sodium acetate $(0.05$ equiv, $0.013 \mathrm{mmol}, 1.0 \mathrm{mg})$ in toluene $(1 \mathrm{~mL})$ at $80^{\circ} \mathrm{C}$ for $1 \mathrm{~h}$. Next, a $4 \mathrm{~mL}$ screw cap vial equipped with a stirring bar was charged with $N$-ethyl maleimide (34.4 mg, 1.1 equiv, $0.275 \mathrm{mmol}$ ), the solution of Ru-1 and sodium acetate, and an alcohol (1 equiv, $0.25 \mathrm{mmol}$ ). The vial was then sealed with a Teflon-lined screw cap, placed in a pre-heated heating block at $80{ }^{\circ} \mathrm{C}$, and allowed to stir for $5 \mathrm{~h}$ at $800 \mathrm{rpm}$. (In the meantime, a solution of $\mathbf{R u - 2}$ was prepared by allowing to stir $\left[\mathrm{Ru}(p \text {-cymene)Cl}]_{2}(0.025\right.$ equiv, $0.0063 \mathrm{mmol}, 3.8 \mathrm{mg})$, me-bipam $(0.055$ equiv, $0.0138 \mathrm{mmol}, 10.5 \mathrm{mg})$ in toluene $(1 \mathrm{~mL})$ for $0.5 \mathrm{~h}$ at room temperature. Also, a solution of $\mathrm{K}_{3} \mathrm{CO}_{3}(1$ equiv, $0.25 \mathrm{mmol}, 34.5 \mathrm{mg})$ in water $(150 \mathrm{uL})$ was prepared). Upon cooling to room temperature, the vial was opened, the solution of Ru-2, the solution of $\mathrm{K}_{3} \mathrm{CO}_{3}$, and an aryl boronic acid (3 equiv, 0.75 mmol) were added. The vial was then resealed with the screw cap, removed from the glove box, placed in a pre-heated heating block at $60{ }^{\circ} \mathrm{C}$, and allowed to stir for $6 \mathrm{~h}$ at $800 \mathrm{rpm}$. The reaction mixture was allowed to cool to room temperature. The mixture was diluted with DCM (50 mL), followed by addition of Celite $(5 \mathrm{~g})$. The volatiles were removed under reduced pressure. The solid residue was subjected to flash column chromatography on silica gel (12 g), conducted with the aid of a CombiFlash EZ Pack instrument using a mixture of petroleum ether and ethyl acetate (typically with a gradient from 100:0 to 85:15) as the eluent. The fractions containing the product (based on TLC and/or GC analysis were combined, and the solvent was evaporated, yielding the product.

\section{Characterization of Products.}

(S)-1-Phenylhexan-1-ol (3aa): Compound 3aa was prepared according to the general procedure with $(S, S)$-me-bipam, by reaction of hexan-1-ol ( $0.25 \mathrm{mmol}, 31.4 \mathrm{uL})$, with phenyl boronic acid $(0.75 \mathrm{mmol}, 91.4 \mathrm{mg})$ and was isolated by column chromatography (silica gel, petroleum ether/ethyl acetate from 100:0 to 85:15) to give a volatile colorless oil in 80\% yield (35.6 mg). The analytical data are consistent with the ones previously reported. ${ }^{18}{ }^{1} \mathrm{H}$ NMR $\left(500 \mathrm{MHz}, \mathrm{CDCl}_{3}\right) \delta 7.39-7.32(\mathrm{~m}, 4 \mathrm{H}), 7.32-7.23(\mathrm{~m}, 1 \mathrm{H}), 4.67(\mathrm{dd}, J=$ 7.6, $5.8 \mathrm{~Hz}, 1 \mathrm{H}), 1.86-1.65(\mathrm{~m}, 3 \mathrm{H}), 1.49-1.35(\mathrm{~m}, 1 \mathrm{H}), 1.34-1.28(\mathrm{~m}, 5 \mathrm{H}), 0.96-0.81(\mathrm{~m}, 3 \mathrm{H}) .{ }^{13} \mathrm{C}\left\{{ }^{1} \mathrm{H}\right\} \mathrm{NMR}(126 \mathrm{MHz}$ $\left.\mathrm{CDCl}_{3}\right) \delta 145.0,128.5,127.5,125.9,74.8,39.1,31.8,25.6,22.6,14.1$. HRMS (ESI+-Orbitrap): m/z calc. for: $\mathrm{C}_{12} \mathrm{H}_{17}: 161.1325$ [M+H$\left.\mathrm{H}_{2} \mathrm{O}\right]^{+}$, found: $161.1327 . . \mathrm{SFC}$ (Chiralpak IG-3, $\mathrm{iPrOH} / \mathrm{CO}_{2}=3 / 97$, flow rate $\left.=1.2 \mathrm{~mL} / \mathrm{min}, 1=210 \mathrm{~nm}\right) \mathrm{tR}=3.18 \mathrm{~min}(\mathrm{major},(S)-$ 3aa), 3.51 min (minor, $(R)-3 \mathbf{a a})$. Specific rotation: $[\alpha]_{\mathrm{D}}{ }^{23}-28.8^{\circ}\left(\mathrm{c} 0.98, \mathrm{CHCl}_{3}\right)$ for an enantiomerically enriched sample of $96: 4$ er.

The absolute configuration was determined by comparison of the sign and the value of the optical rotation with that reported in literature for the opposite enantiomer $[\alpha]_{\mathrm{D}}{ }^{20}+31.6^{\circ}\left(\mathrm{c} 1.0, \mathrm{CHCl}_{3}\right), 96: 4^{18}$ Scale-up: Compound 3aa was also prepared on a 1.75 mmol scale according to the general procedure with $(S, S)$-me-bipam, by reaction of hexan-1-ol (1.75 mmol, $219.6 \mathrm{uL})$, with phenyl boronic acid $(5.25 \mathrm{mmol}, 640.1 \mathrm{mg})$ and was isolated by column chromatography (silica gel, petroleum ether/ethyl acetate from 100:0 to $85: 15)$ to give a volatile colorless oil in $84 \%$ yield $(262.4 \mathrm{mg})$ with the same NMR data and $96: 4$ er.

(S)-1-phenylhex-5-en-1-ol (3ga): Compound 3ga was prepared according to the general procedure with $(S, S)$-me-bipam, by reaction of hexen-1-ol $(0.25 \mathrm{mmol}, 30.0 \mathrm{uL})$, with phenyl boronic acid $(0.75 \mathrm{mmol}, 91.4 \mathrm{mg})$ and was isolated by column chromatography (silica gel, petroleum ether to petroleum ether/ethyl acetate $85: 15$ ) to give a volatile colourless oil in $79 \%$ yield (35.0 mg). The analytical data are consistent with the ones previously reported. ${ }^{40}{ }^{1} \mathrm{H} \mathrm{NMR}\left(500 \mathrm{MHz}, \mathrm{CDCl}_{3}\right) \delta 7.36-7.31(\mathrm{~m}, 4 \mathrm{H}), 7.31-7.24(\mathrm{~m}$, $1 \mathrm{H}), 5.84-5.72(\mathrm{~m}, 1 \mathrm{H}), 5.03-4.91(\mathrm{~m}, 2 \mathrm{H}), 4.68(\mathrm{dd}, J=7.6,5.7 \mathrm{~Hz}, 1 \mathrm{H}), 2.14-2.03(\mathrm{~m}, 2 \mathrm{H}), 1.89-1.67(\mathrm{~m}, 3 \mathrm{H}), 1.62-1.47$ $(\mathrm{m}, 1 \mathrm{H}), 1.45-1.33(\mathrm{~m}, 1 \mathrm{H}) .{ }^{13} \mathrm{C}\left\{{ }^{1} \mathrm{H}\right\} \mathrm{NMR}\left(126 \mathrm{MHz}, \mathrm{CDCl}_{3}\right) \delta 144.8,138.6,128.5,127.6,125.9,114.7,74.6,38.5,33.6,25.1$. HRMS (ESI+-Orbitrap): m/z calc. for: $\mathrm{C}_{12} \mathrm{H}_{15}: 159.1168\left[\mathrm{M}+\mathrm{H}-\mathrm{H}_{2} \mathrm{O}\right]^{+}$, found: $159.1172 . . \mathrm{SFC}(\mathrm{Chiralpak} \mathrm{IG}-3, \mathrm{iPrOH} / \mathrm{CO} 2=5 / 95$, 
flow rate $=1.2 \mathrm{~mL} / \mathrm{min}, 1=210 \mathrm{~nm}) \mathrm{tR}=2.44 \min ($ major, $(S)-3 g a), 2.65 \min (\operatorname{minor},(R)-3 g a)$. Specific rotation: $[\alpha]_{\mathrm{D}}^{23}-41.2^{\circ}(\mathrm{c}$ $1.0, \mathrm{CHCl}_{3}$ ) for an enantiomerically enriched sample of 98:2 er. The absolute configuration was determined by comparison of the sign and the value of the optical rotation with that reported in literature for the opposite enantiomer $[\alpha]_{\mathrm{D}}^{20}+38.0^{\circ}\left(\mathrm{c} 1.1, \mathrm{CHCl}_{3}\right)$, $92: 8 .^{40}$

(S)-2-methyl-1-phenylpropan-1-ol (3ha): Compound 3ha was prepared according to the general procedure with (S,S)-me-bipam, by reaction of 2-methylpropan-1-ol $(0.25 \mathrm{mmol}, 23.1 \mathrm{uL})$, with phenyl boronic acid $(0.75 \mathrm{mmol}, 91.4 \mathrm{mg})$ and was isolated by column chromatography (silica gel, n-pentane to dichloromethane ) to give a volatile colourless oil in $80 \%$ yield (35.0 mg). The analytical data are consistent with the ones previously reported. ${ }^{41}{ }^{1} \mathrm{H}$ NMR $\left(500 \mathrm{MHz}, \mathrm{CDCl}_{3}\right) \delta 7.37-7.30(\mathrm{~m}, 4 \mathrm{H}), 7.29-7.27(\mathrm{~m}, 1 \mathrm{H}), 4.37$ $(\mathrm{d}, J=6.9 \mathrm{~Hz}, 1 \mathrm{H}), 1.96(\mathrm{dq}, J=13.4,6.7 \mathrm{~Hz}, 1 \mathrm{H}), 1.78(\mathrm{bs}, 1 \mathrm{H}), 1.01(\mathrm{~d}, J=6.7 \mathrm{~Hz}, 3 \mathrm{H}), 0.80(\mathrm{~d}, J=6.8 \mathrm{~Hz}, 3 \mathrm{H}) .{ }^{13} \mathrm{C} \mathrm{NMR}(126$ $\left.\mathrm{MHz}_{\mathrm{CDCl}}\right) \delta 143.6,128.2,127.5,126.6,80.1,35.3,19.0,18.3$. HRMS (ESI+-Orbitrap): m/z calc. for: $\mathrm{C}_{10} \mathrm{H}_{13}: 133.1012$ [M+H$\left.\mathrm{H}_{2} \mathrm{O}\right]^{+}$, found: 133.1019 . SFC (Chiralpak IG-3, $\mathrm{PrOH} / \mathrm{CO}_{2}=2.5 / 97.5$, flow rate $\left.=1.2 \mathrm{~mL} / \mathrm{min}, 1=210 \mathrm{~nm}\right) \mathrm{tR}=3.44 \mathrm{~min}(\mathrm{major}$, $(S)-3 \mathbf{h a}), 3.19 \mathrm{~min}$ (minor, $(R)-3 \mathrm{ha})$. Specific rotation: $[\alpha]_{\mathrm{D}}{ }^{23}-39.4^{\mathrm{o}}\left(\mathrm{c} 0.97, \mathrm{Et}_{2} \mathrm{O}\right)$ for an enantiomerically enriched sample of $96: 4$ er. The absolute configuration was determined by comparison of the sign and the value of the optical rotation with that reported in literature for the opposite enantiomer $[\alpha]_{\mathrm{D}}^{25}+39.3^{\circ}\left(\mathrm{c} 1.25, \mathrm{Et}_{2} \mathrm{O}\right), 94: 6^{41}$

(S)-2-Cyclohexyl-1-phenylethan-1-ol (3ia): Compound 3ia was prepared according to the general procedure with (S,S)-me-bipam, by reaction of 2-cyclohexylethan-1-ol $(0.25 \mathrm{mmol}, 34.9 \mathrm{uL})$, with phenyl boronic acid $(0.75 \mathrm{mmol}, 91.4 \mathrm{mg})$ and was isolated by column chromatography (silica gel, petroleum ether to petroleum ether/ethyl acetate 85:15) to give a white, amorphous solid in $82 \%$ yield (42.0 mg). The analytical data are consistent with the ones previously reported. ${ }^{42}{ }^{1} \mathrm{H} \mathrm{NMR}\left(500 \mathrm{MHz}, \mathrm{CDCl}_{3}\right) \delta 7.37-7.31(\mathrm{~m}$, $4 \mathrm{H}), 7.31-7.24(\mathrm{~m}, 1 \mathrm{H}), 4.79(\mathrm{dd}, J=8.8,5.1 \mathrm{~Hz}, 1 \mathrm{H}), 1.86-1.75(\mathrm{~m}, 1 \mathrm{H}), 1.78-1.48(\mathrm{~m}, 7 \mathrm{H}), 1.46-1.34(\mathrm{~m}, 1 \mathrm{H}), 1.30-1.09$ $(\mathrm{m}, 3 \mathrm{H}), 1.03-0.86(\mathrm{~m}, 2 \mathrm{H}) .{ }^{13} \mathrm{C}\left\{{ }^{1} \mathrm{H}\right\} \mathrm{NMR}\left(126 \mathrm{MHz}, \mathrm{CDCl}_{3}\right) \delta 145.4,128.5,127.5,125.8,72.1,47.1,34.3,34.0,32.9,26.6,26.3$, 26.2. HRMS (ESI ${ }^{+}-$Orbitrap): m/z calc. for: $\mathrm{C}_{14} \mathrm{H}_{19}$ : $187.1481\left[\mathrm{M}+\mathrm{H}-\mathrm{H}_{2} \mathrm{O}\right]^{+}$, found: 187.1438. SFC $(\mathrm{Chiralpak} \mathrm{IA}-3$, iPrOH/CO $2=$ $5 / 95$, flow rate $=1.2 \mathrm{~mL} / \mathrm{min}, 1=210 \mathrm{~nm}) \mathrm{tR}=4.15 \mathrm{~min}$ (major, $(S)-3 i a), 4.85 \mathrm{~min}($ minor, $(R)-3 i a)$. Specific rotation: $[\alpha]_{\mathrm{D}}^{23}-21.7^{\circ}$ (c 1.0, $\mathrm{CHCl}_{3}$ ) for an enantiomerically enriched sample of 95:5 er. The absolute configuration was determined by analogy to compound $(S)$-3aa.

(S)-2-(4-methoxyphenyl)-1-phenylethan-1-ol (3ja): Compound 3ja was prepared according to the general procedure with (S,S)-mebipam, by reaction of 2-(4-methoxyphenyl)ethan-1-ol $(0.25 \mathrm{mmol}, 34.6 \mathrm{uL})$, with phenyl boronic acid $(0.75 \mathrm{mmol}, 91.4 \mathrm{mg})$ and was isolated by column chromatography (silica gel, petroleum ether to petroleum ether/ethyl acetate 85:15) to give a white solid in $44 \%$ yield $(25.3 \mathrm{mg})$. The analytical data are consistent with the ones previously reported. ${ }^{43}{ }^{1} \mathrm{H} \mathrm{NMR}\left(500 \mathrm{MHz}, \mathrm{CDCl}_{3}\right) \delta 7.38-$ $7.33(\mathrm{~m}, 4 \mathrm{H}), 7.31-7.27(\mathrm{~m}, 1 \mathrm{H}), 7.14-7.08(\mathrm{~m}, 2 \mathrm{H}), 6.88-6.81(\mathrm{~m}, 2 \mathrm{H}), 4.86(\mathrm{dd}, J=8.5,4.8 \mathrm{~Hz}, 1 \mathrm{H}), 3.80(\mathrm{~s}, 3 \mathrm{H}), 3.03-2.89$ $(\mathrm{m}, 2 \mathrm{H}), 1.63-1.46$ (br, $1 \mathrm{H}) .{ }^{13} \mathrm{C}\left\{{ }^{1} \mathrm{H}\right\} \mathrm{NMR}\left(126 \mathrm{MHz}, \mathrm{CDCl}_{3}\right) \delta 158.4,143.9,130.5,130.0,128.4,127.6,125.9,114.0,75.4,55.3$, 45.2. HRMS (ESI ${ }^{+}$-Orbitrap): m/z calc. for: $\mathrm{C}_{15} \mathrm{H}_{15} \mathrm{O}: 211.1117\left[\mathrm{M}+\mathrm{H}-\mathrm{H}_{2} \mathrm{O}\right]^{+}$, found: 211.1119. SFC $(\mathrm{Chiralpak} \mathrm{IH}-3$, iPrOH/CO $2=$ $5 / 95$, flow rate $=1.2 \mathrm{~mL} / \mathrm{min}, 1=210 \mathrm{~nm}) \mathrm{tR}=5.96 \mathrm{~min}$ (major, $(S)-3 \mathbf{j a}), 7.47 \mathrm{~min}(\operatorname{minor},(R)-3 \mathbf{j a})$. Specific rotation: $[\alpha]_{\mathrm{D}}^{23}-2.8^{\circ}$ (c $0.87, \mathrm{CHCl}_{3}$ ) for an enantiomerically enriched sample of 93:7 er. The absolute configuration was determined by comparison of the sign and the value of the optical rotation with that reported in literature for the opposite enantiomer $[\alpha]_{\mathrm{D}}{ }^{22}+3.8^{\circ}\left(\mathrm{c} 1.4, \mathrm{CHCl}_{3}\right), 94: 6 .^{43}$

(S)-Isopropyl 6-hydroxy-6-phenylhexanoate (3ka): Compound 3ka was prepared according to the general procedure with (S,S)me-bipam, by reaction of isopropyl 6-hydroxyhexanoate (1k, $0.25 \mathrm{mmol}, 43.6 \mathrm{mg})$, with phenyl boronic acid (0.75 mmol, $91.4 \mathrm{mg})$ and was isolated by column chromatography (silica gel, petroleum ether to petroleum ether/ethyl acetate 85:25) to give a white, amorphous solid in $66 \%$ yield (41.1 mg). ${ }^{1} \mathrm{H}$ NMR (500 MHz, $\left.\mathrm{CDCl}_{3}\right) \delta 7.37-7.32(\mathrm{~m}, 4 \mathrm{H}), 7.31-7.27(\mathrm{~m}, 1 \mathrm{H}), 4.98(\mathrm{hept}, J=6.3$ $\mathrm{Hz}, 1 \mathrm{H}), 4.68(\mathrm{dd}, J=7.6,5.7 \mathrm{~Hz}, 1 \mathrm{H}), 2.25(\mathrm{t}, J=7.5 \mathrm{~Hz}, 2 \mathrm{H}), 1.93-1.78(\mathrm{~m}, 1 \mathrm{H}), 1.73-1.53(\mathrm{~m}, 4 \mathrm{H}), 1.51-1.39(\mathrm{~m}, 2 \mathrm{H}), 1.28$ $-1.17(\mathrm{~m}, 6 \mathrm{H}) .{ }^{13} \mathrm{C}\left\{{ }^{1} \mathrm{H}\right\} \mathrm{NMR}\left(126 \mathrm{MHz}, \mathrm{CDCl}_{3}\right) \delta 173.4,144.8,128.6,127.7,126.0,74.5,67.6,38.8,34.7,25.4,25.0,22.0 . \mathrm{HRMS}$ (ESI+-Orbitrap): m/z calc. for: $\mathrm{C}_{15} \mathrm{H}_{22} \mathrm{O}_{2}: 233.1536\left[\mathrm{M}+\mathrm{H}-\mathrm{H}_{2} \mathrm{O}\right]^{+}$, found: 233.1541. SFC $($Chiralpak IC-3, iPrOH/CO $=5 / 95$, flow rate $=1.2 \mathrm{~mL} / \mathrm{min}, 1=210 \mathrm{~nm}) \mathrm{tR}=6.55 \mathrm{~min}($ major, $(S)-3 \mathbf{k a}), 7.24 \mathrm{~min}(\operatorname{minor},(R)-3 \mathbf{k a})$. Specific rotation: $[\alpha]_{\mathrm{D}}^{23}-19.6^{\circ}(\mathrm{c} 1.02$, 
$\mathrm{CHCl}_{3}$ ) for an enantiomerically enriched sample of 95:5 er. The absolute configuration was determined by analogy to compound ( $S$ )3aa.

Hydroxy-6-phenyl-1-(piperidin-1-yl)hexan-1-one (3la): Compound 3la was prepared according to the general procedure with (S,S)me-bipam, except the loading of Ru-2 was doubled, by reaction of 6-hydroxy-1-(piperidin-1-yl)hexan-1-one (11, 0.20 mmol, 39.8 $\mathrm{mg})$, with phenyl boronic acid $(0.60 \mathrm{mmol}, 73.2 \mathrm{mg})$ and was isolated by column chromatography (silica gel, petroleum ether to ethyl acetate) to give a greenish oil in $51 \%$ yield $(28.3 \mathrm{mg}) .{ }^{1} \mathrm{H}$ NMR $\left(500 \mathrm{MHz}, \mathrm{CDCl}_{3}\right) \delta 7.36-7.31(\mathrm{~m}, 4 \mathrm{H}), 7.30-7.26(\mathrm{~m}, 1 \mathrm{H}), 4.70$ $(\mathrm{dd}, J=8.0,5.5 \mathrm{~Hz}, 1 \mathrm{H}), 3.52(\mathrm{t}, J=5.5 \mathrm{~Hz}, 2 \mathrm{H}), 3.36(\mathrm{t}, J=5.4 \mathrm{~Hz}, 2 \mathrm{H}), 2.29(\mathrm{t}, J=7.5 \mathrm{~Hz}, 2 \mathrm{H}), 2.20(\mathrm{~s}, 1 \mathrm{H}), 1.90-1.58(\mathrm{~m}, 6 \mathrm{H})$, $1.56-1.42(\mathrm{~m}, 5 \mathrm{H}), 1.41-1.27(\mathrm{~m}, 1 \mathrm{H}) .{ }^{13} \mathrm{C}\left\{{ }^{1} \mathrm{H}\right\} \mathrm{NMR}\left(126 \mathrm{MHz}, \mathrm{CDCl}_{3}\right) \delta 171.3,145.0,128.4,127.4,125.9,74.1,46.7,42.7$, 38.9, 33.2, 26.5, 25.7, 25.6, 25.0, 24.6. HRMS (ESI+-Orbitrap): m/z calc. for: $\mathrm{C}_{17} \mathrm{H}_{24} \mathrm{NO}: 258.1852$ [M+H-H$\left.{ }_{2} \mathrm{O}\right]^{+}$, found: 258.1857 . SFC (Chiralpak IA-3, iPrOH/CO $\mathrm{CO}_{2}=13 / 87$, flow rate $\left.=1.2 \mathrm{~mL} / \mathrm{min}, 1=210 \mathrm{~nm}\right) \mathrm{tR}=6.79 \mathrm{~min}($ major, $(S)-31 \mathbf{a}), 7.15 \mathrm{~min}(\mathrm{minor},(R)$ 3la). Specific rotation: $[\alpha]_{\mathrm{D}}^{23}-12.6^{\circ}\left(\mathrm{c} 1.02, \mathrm{CHCl}_{3}\right)$ for an enantiomerically enriched sample of $98: 2$ er. The absolute configuration was determined by analogy to compound $(S)$-3aa.

(S)-N-cyclohexyl-6-hydroxy-6-phenylhexanamide (3ma): Compound 3ma was prepared according to the general procedure with $(S, S)$-me-bipam, except the loading of Ru-2 was doubled, by reaction of $N$-cyclohexyl-6-hydroxyhexamide (1 m, 0.25 mmol, 53.3 $\mathrm{mg})$, with phenyl boronic acid $(0.75 \mathrm{mmol}, 91.4 \mathrm{mg}$ ) and was isolated by column chromatography (silica gel, petroleum ether to ethyl acetate) to give a greenish, amorphous solid in 55\% yield (39.6 mg). ${ }^{1} \mathrm{H} \mathrm{NMR}\left(500 \mathrm{MHz}, \mathrm{CDCl}_{3}\right) \delta 7.38-7.31(\mathrm{~m}, 4 \mathrm{H}), 7.31-7.23$ $(\mathrm{m}, 1 \mathrm{H}), 5.24(\mathrm{~d}, J=8.3 \mathrm{~Hz}, 1 \mathrm{H}), 4.68(\mathrm{dd}, J=7.7,5.6 \mathrm{~Hz}, 1 \mathrm{H}), 3.88-3.59(\mathrm{~m}, 1 \mathrm{H}), 2.18-2.06(\mathrm{~m}, 2 \mathrm{H}), 2.04-1.52(\mathrm{~m}, 11 \mathrm{H}), 1.52$ - $1.28(\mathrm{~m}, 3 \mathrm{H}), 1.21-0.87(\mathrm{~m}, 3 \mathrm{H}) .{ }^{13} \mathrm{C}\left\{{ }^{1} \mathrm{H}\right\} \mathrm{NMR}\left(126 \mathrm{MHz}, \mathrm{CDCl}_{3}\right) \delta 171.9,144.8,128.5,127.5,125.9,74.3,48.1,38.7,36.9$, 33.3, 25.6, 25.5, 25.4, 24.9. HRMS (ESI+-Orbitrap): m/z calc. for: $\mathrm{C}_{18} \mathrm{H}_{26} \mathrm{NO}: 272.2009$ [M+H-H$\left.{ }_{2} \mathrm{O}\right]^{+}$, found: 272.2011 . SFC (Chiralpak IC-3, $\mathrm{iPrOH} / \mathrm{CO}_{2}=20 / 80$, flow rate $\left.=1.2 \mathrm{~mL} / \mathrm{min}, 1=210 \mathrm{~nm}\right) \mathrm{tR}=6.69 \mathrm{~min}($ major, $(S)-3 \mathrm{ma}), 8.15 \mathrm{~min}(\mathrm{minor},(R)-3 \mathrm{ma})$. Specific rotation: $[\alpha]_{\mathrm{D}}^{23}-16.8^{\circ}\left(\mathrm{c} 1.0, \mathrm{CHCl}_{3}\right)$ for an enantiomerically enriched sample of $96: 4$ er. The absolute configuration was determined by analogy to compound $(S)$-3aa.

(S)-2-(5-hydroxy-5-phenylpentyl)isoindoline-1,3-dione (3na): Compound 3na was prepared according to the general procedure with $(S, S)$-me-bipam, except the loading of Ru-2 was doubled, by reaction of 2-(5-hydroxypentyl)isoindoline-1,3-dione (1n, 0.25 mmol, $58.3 \mathrm{mg})$, with phenyl boronic acid $(0.75 \mathrm{mmol}, 91.4 \mathrm{mg})$ and was isolated by column chromatography (silica gel, petroleum ether to ethyl acetate) to give a greenish, amorphous solid in $49 \%$ yield $(37.7 \mathrm{mg}) .{ }^{1} \mathrm{H} \mathrm{NMR}\left(500 \mathrm{MHz}, \mathrm{CDCl}_{3}\right) \delta 7.87-7.79(\mathrm{~m}$, 2H), $7.75-7.66(\mathrm{~m}, 2 \mathrm{H}), 7.39-7.29(\mathrm{~m}, 4 \mathrm{H}), 7.29-7.21(\mathrm{~m}, 1 \mathrm{H}), 4.76-4.59(\mathrm{~m}, 1 \mathrm{H}), 3.76-3.58(\mathrm{~m}, 2 \mathrm{H}), 2.02-1.63(\mathrm{~m}, 5 \mathrm{H})$, $1.59-1.29$ (m, 2H). ${ }^{13} \mathrm{C}\left\{{ }^{1} \mathrm{H}\right\}$ NMR $\left(126 \mathrm{MHz}, \mathrm{CDCl}_{3}\right) \delta 168.5,144.7,133.9,132.1,128.5,127.5,125.8,123.2,74.3,38.5,37.8$, 28.4, 23.1. HRMS (ESI ${ }^{+}$-Orbitrap): $\mathrm{m} / \mathrm{z}$ calc. for: $\mathrm{C}_{19} \mathrm{H}_{18} \mathrm{NO}_{2}: 292.1332\left[\mathrm{M}+\mathrm{H}-\mathrm{H}_{2} \mathrm{O}\right]^{+}$, found: 292.1333. SFC (Chiralpak IC-3, $\mathrm{iPrOH} / \mathrm{CO}_{2}=10 / 90$, flow rate $\left.=1.2 \mathrm{~mL} / \mathrm{min}, \mathrm{l}=210 \mathrm{~nm}\right) \mathrm{tR}=6.73 \mathrm{~min}$ (major, $\left.(S)-3 \mathrm{na}\right), 7.13 \mathrm{~min}($ minor, $(R)-3 \mathrm{na})$. Specific rotation: $[\alpha]_{\mathrm{D}}^{23}-14.5^{\circ}\left(\mathrm{c} 1.0, \mathrm{CHCl}_{3}\right)$ for an enantiomerically enriched sample of 97:3 er. The absolute configuration was determined by analogy to compound $(S)$-3aa.

(S)-18-hydroxy-18-phenyloctadecan-7-one (30a): Compound 3oa was prepared according to the general procedure with (S,S)-mebipam, by reaction of 18-hydroxyhexadecane-7-one $(\mathbf{1 0}, 0.13 \mathrm{mmol}, 37.0 \mathrm{mg})$, with phenyl boronic acid $(0.39 \mathrm{mmol}, 47.6 \mathrm{mg})$ and was isolated by column chromatography (silica gel, petroleum ether to petroleum ether/ethyl acetate 85:25) to give a white, amorphous solid in 58\% yield (27.1 mg). ${ }^{1} \mathrm{H}$ NMR $\left(500 \mathrm{MHz}, \mathrm{CDCl}_{3}\right) \delta 7.38-7.31(\mathrm{~m}, 4 \mathrm{H}), 7.30-7.27(\mathrm{~m}, 1 \mathrm{H}), 4.66(\mathrm{dd}, J=7.6,5.8$ $\mathrm{Hz}, 1 \mathrm{H}), 2.37$ (td, $J=7.5,2.4 \mathrm{~Hz}, 4 \mathrm{H}), 2.04-1.62(\mathrm{~m}, 2 \mathrm{H}), 1.67-1.52(\mathrm{~m}, 4 \mathrm{H}), 1.47-1.37$ (m, $1 \mathrm{H}), 1.34-1.10(\mathrm{~m}, 20 \mathrm{H}), 0.95-$ $0.72(\mathrm{~m}, 3 \mathrm{H}) .{ }^{13} \mathrm{C}\left\{{ }^{1} \mathrm{H}\right\}$ NMR $\left(126 \mathrm{MHz}, \mathrm{CDCl}_{3}\right) \delta 211.9,145.0,128.4,127.5,125.9,74.7,42.8,42.8,39.1,31.6,29.5,29.5,29.5$, 29.4, 29.4, 29.3, 29.0, 25.8, 23.9, 23.9, 22.5, 14.1. HRMS (ESI+-Orbitrap): m/z calc. for: $\mathrm{C}_{24} \mathrm{H}_{39} \mathrm{O}: 343.2995$ [M+H-H$\left.{ }_{2} \mathrm{O}\right]^{+}$, found: 343.2998. SFC (Chiralpak IA-3, $\mathrm{iPrOH} / \mathrm{CO}_{2}=8.5 / 91.5$, flow rate $\left.=1.2 \mathrm{~mL} / \mathrm{min}, 1=210 \mathrm{~nm}\right) \mathrm{tR}=6.41 \mathrm{~min}(\mathrm{major},(S)-30 a), 6.01$ $\min (\operatorname{minor},(R)-30 a)$. Specific rotation: $[\alpha]_{\mathrm{D}}{ }^{24}-12.0^{\circ}\left(\mathrm{c} 0.99, \mathrm{CHCl}_{3}\right)$ for an enantiomerically enriched sample of $97: 3$ er. The absolute configuration was determined by analogy to compound $(S)$-3aa. 
(1S,12-R/S)-1-phenyloctadecane-1,12-diol (3pa): Compound 3pa was prepared according to the general procedure with $(S, S)$-mebipam, by reaction of rac-octadecane-1,12-diol (rac-1p, $0.25 \mathrm{mmol}, 71.6 \mathrm{mg}$ ), with phenyl boronic acid (0.75 mmol, $91.4 \mathrm{mg})$ and was isolated by column chromatography (silica gel, petroleum ether to petroleum ether/ethyl acetate 85:25) to give a white, amorphous solid in $64 \%$ yield $(58.0 \mathrm{mg})$. The isolated material contains both diastereomers that are indistinguishable by ${ }^{1} \mathrm{H}$ and ${ }^{13} \mathrm{C} \mathrm{NMR}$ spectroscopy. The diastereomeric ratio, which reflects the stereoselectivity of the formation of the new stereogenic center, was determined by SFC analysis for the diester of p-nitrobenzoic acid derivative of 3pa (3pa', 1-phenyloctadecane-1,12-diylbis(4-nitrobenzoate)), which was prepared following a literature procedure. ${ }^{44} \mathrm{H} \mathrm{NMR}\left(500 \mathrm{MHz}, \mathrm{CDCl}_{3}\right) \delta 7.38-7.32(\mathrm{~m}, 4 \mathrm{H}), 7.31-7.26(\mathrm{~m}, 1 \mathrm{H})$, $4.66(\mathrm{dd}, J=7.6,5.8 \mathrm{~Hz}, 1 \mathrm{H}), 3.62-3.54(\mathrm{~m}, 1 \mathrm{H}), 2.01-1.63(\mathrm{~m}, 2 \mathrm{H}), 1.55-1.36(\mathrm{~m}, 7 \mathrm{H}), 1.36-1.17(\mathrm{~m}, 23 \mathrm{H}), 0.97-0.77(\mathrm{~m}$, $3 \mathrm{H}) .{ }^{13} \mathrm{C}\left\{{ }^{1} \mathrm{H}\right\} \mathrm{NMR}\left(126 \mathrm{MHz}, \mathrm{CDCl}_{3}\right) \delta 145.0,128.4,127.5,125.9,74.7,72.1,39.1,37.5,37.5,31.9,29.7,29.6,29.6,29.6,29.5$, 29.5, 29.4, 25.8, 25.7, 25.6, 22.6, 14.1. HRMS (ESI+-Orbitrap): m/z calc. for: $\mathrm{C}_{24} \mathrm{H}_{41} \mathrm{O}: 327.3046$ [M+H- $\left.\mathrm{H}_{2} \mathrm{O}\right]^{+}$, found: 327.3046 . SFC of diester derivative (Chiralpak IA-3, iPrOH/CO $\mathrm{CO}_{2}=20 / 80$, flow rate = $\left.1.2 \mathrm{~mL} / \mathrm{min}, 1=254 \mathrm{~nm}\right) \mathrm{tR}=2.44 \mathrm{~min}(\mathrm{major},(S)-3 p a ')$, 2.65 min (minor, $(R)-3$ pa'). Specific rotation: $[\alpha]_{\mathrm{D}}{ }^{24}-14.1^{\circ}\left(\mathrm{c} 1.01, \mathrm{CHCl}_{3}\right)$ for a sample containing a $97: 3$ mixture of $(1 S, 12-R / S)$ 3pa and $(1 R, 12-R / S)-3 p a$. The absolute configuration of the newly formed stereocenter was determined by analogy to compound $(S)$ 3aa.

(S)-1-([1,1'-biphenyl]-4-yl)hexan-1-ol (3ab): Compound 3ab was prepared according to the general procedure with (S,S)-mebipam, except the reaction was heated to $90^{\circ} \mathrm{C}$ during the hydroarylation step instead of $60{ }^{\circ} \mathrm{C}$, by reaction of hexan-1-ol $(0.25$ mmol, $31.4 \mathrm{uL}$ ), with 2 4-biphenylboronic acid $(0.75 \mathrm{mmol}, 148.5 \mathrm{mg}$ ) and was isolated by column chromatography (silica gel, petroleum ether to petroleum ether/ethyl acetate 85:15) to give a white, amorphous solid in 54\% yield (32.4 mg). The analytical data are consistent with the ones previously reported. ${ }^{18}{ }^{1} \mathrm{H} \mathrm{NMR}\left(500 \mathrm{MHz}, \mathrm{CDCl}_{3}\right) \delta 7.68-7.53(\mathrm{~m}, 4 \mathrm{H}), 7.51-7.40(\mathrm{~m}, 4 \mathrm{H}), 7.39-$ $7.31(\mathrm{~m}, 1 \mathrm{H}), 4.72(\mathrm{t}, J=6.7 \mathrm{~Hz}, 1 \mathrm{H}), 1.91-1.67(\mathrm{~m}, 3 \mathrm{H}), 1.46(\mathrm{~m}, 1 \mathrm{H}), 1.37-1.22(\mathrm{~m}, 5 \mathrm{H}), 0.88(\mathrm{~m}, 3 \mathrm{H}) .{ }^{13} \mathrm{C}\left\{{ }^{1} \mathrm{H}\right\} \mathrm{NMR}(126$ $\left.\mathrm{MHz}, \mathrm{CDCl}_{3}\right) \delta 144.0,140.9,140.4,128.8,127.3,127.2,127.1,126.4,74.5,39.1,31.8,25.6,22.6,14.1 . \mathrm{HRMS}_{\text {(ESI }}^{+}$-Orbitrap): m/z calc. for: $\mathrm{C}_{18} \mathrm{H}_{21}: 237.1638\left[\mathrm{M}+\mathrm{H}-\mathrm{H}_{2} \mathrm{O}\right]^{+}$, found: 237.1637. SFC (Chiralpak IG-3, $\mathrm{iPrOH} / \mathrm{CO}_{2}=10 / 90$, flow rate $=1.2 \mathrm{~mL} / \mathrm{min}, 1=$ $210 \mathrm{~nm}$ ) $\mathrm{tR}=4.52 \mathrm{~min}$ (major, $(S)-3 \mathbf{a b}), 5.65 \mathrm{~min}$ (minor, $(R)-3 \mathbf{a b})$. Specific rotation: $[\alpha]_{\mathrm{D}}^{23}-17.7^{\circ}\left(\mathrm{c} 1.0, \mathrm{CHCl}_{3}\right)$ for an enantiomerically enriched sample of 92:8 er. The absolute configuration was determined by comparison of the sign and the value of the optical rotation with that reported in literature for the opposite enantiomer $[\alpha]_{\mathrm{D}}{ }^{20}+23.4^{\mathrm{o}}\left(\mathrm{c} 0.94, \mathrm{CHCl}_{3}\right), 95: 5$. $^{18}$

(S)-1-(4-Fluorophenyl)hexan-1-ol (3ac): Compound 3ac was prepared according to the general procedure with $(S, S)$-me-bipam, by reaction of hexan-1-ol $(0.25 \mathrm{mmol}, 31.4 \mathrm{uL})$, with 4-fluorophenyl boronic acid $(0.75 \mathrm{mmol}, 104.9 \mathrm{mg})$ and was isolated by column chromatography (silica gel, petroleum ether to petroleum ether/ethyl acetate 85:15) to give a white, amorphous solid in $77 \%$ yield (37.9 mg). The analytical data are consistent with the ones previously reported. ${ }^{18}{ }^{1} \mathrm{H} \mathrm{NMR}\left(500 \mathrm{MHz}, \mathrm{CDCl}_{3}\right) \delta 7.38-7.28(\mathrm{~m}, 2 \mathrm{H})$, $7.07-6.98(\mathrm{~m}, 2 \mathrm{H}), 4.65(\mathrm{dd}, J=7.5,5.9 \mathrm{~Hz}, 1 \mathrm{H}), 1.87-1.73(\mathrm{~m}, 2 \mathrm{H}), 1.71-1.59(\mathrm{~m}, 1 \mathrm{H}), 1.47-1.35(\mathrm{~m}, 1 \mathrm{H}), 1.29(\mathrm{dt}, J=7.0$, $3.7 \mathrm{~Hz}, 5 \mathrm{H}), 0.92-0.82(\mathrm{~m}, 3 \mathrm{H}) .{ }^{13} \mathrm{C}\left\{{ }^{1} \mathrm{H}\right\} \mathrm{NMR}\left(126 \mathrm{MHz}, \mathrm{CDCl}_{3}\right) \delta 162.1(\mathrm{~d}, J=245.1 \mathrm{~Hz}), 140.6(\mathrm{~d}, J=3.1 \mathrm{~Hz}), 127.5(\mathrm{~d}, J=8.0$ $\mathrm{Hz}), 115.2(\mathrm{~d}, J=21.3 \mathrm{~Hz}), 74.1(\mathrm{~d}, J=0.7 \mathrm{~Hz}), 39.2(\mathrm{~d}, J=0.8 \mathrm{~Hz}), 31.7,25.5,22.6,14.0 .{ }^{19} \mathrm{~F} \mathrm{NMR}\left(471 \mathrm{MHz}, \mathrm{CDCl}_{3}\right) \delta-115.25$ - -115.34 (m). HRMS (ESI+-Orbitrap): m/z calc. for: $\mathrm{C}_{12} \mathrm{H}_{16} \mathrm{~F}: 179.1231$ [M+H-H $\mathrm{H}^{+}$, found: 179.1230. SFC (Chiralpak IG-3, $\mathrm{iPrOH} / \mathrm{CO}_{2}=5 / 95$, flow rate $=1.2 \mathrm{~mL} / \mathrm{min}, 1=210 \mathrm{~nm}$ ) $\mathrm{tR}=1.83 \mathrm{~min}$ (major, $\left.(S)-3 \mathrm{ac}\right), 2.03 \mathrm{~min}($ minor, $(R)-3 \mathrm{ac})$. Specific rotation: $[\alpha]_{\mathrm{D}}^{23}-26.6^{\circ}\left(\mathrm{c} 0.98, \mathrm{CHCl}_{3}\right)$ for an enantiomerically enriched sample of 96:4 er. The absolute configuration was determined by comparison of the sign and the value of the optical rotation with that reported in literature for the opposite enantiomer $\left([\alpha]_{\mathrm{D}}^{20}+29.3^{\circ}\right.$ (c $\left.1.03, \mathrm{CHCl}_{3}\right), 96: 4$ er.). ${ }^{18}$

(S)-1-(3-Methylphenyl)hexan-1-ol (3ae) : Compound 3ae was prepared according to the general procedure with (S,S)-me-bipam, by reaction of hexan-1-ol $(0.25 \mathrm{mmol}, 31.4 \mathrm{uL})$, with 3-methylphenyl boronic acid $(0.75 \mathrm{mmol}, 109.5 \mathrm{mg})$ and was isolated by column chromatography (silica gel, petroleum ether to petroleum ether/ethyl acetate 85:15) to give a volatile colourless oil in 67\% yield (32.4 $\mathrm{mg})$. The analytical data are consistent with the ones previously reported. ${ }^{18}{ }^{1} \mathrm{H} \mathrm{NMR}\left(500 \mathrm{MHz}, \mathrm{CDCl}_{3}\right) \delta 7.16(\mathrm{t}, J=7.6 \mathrm{~Hz}, 1 \mathrm{H})$, $7.11-6.88(\mathrm{~m}, 3 \mathrm{H}), 4.56(\mathrm{dd}, J=7.6,5.7 \mathrm{~Hz}, 1 \mathrm{H}), 2.29$ (s, 3H), $1.80-1.44(\mathrm{~m}, 3 \mathrm{H}), 1.41-1.31(\mathrm{~m}, 1 \mathrm{H}), 1.28-1.14(\mathrm{~m}, 5 \mathrm{H}), 0.84$ 
- $0.77(\mathrm{~m}, 3 \mathrm{H}) .{ }^{13} \mathrm{C}\left\{{ }^{1} \mathrm{H}\right\} \mathrm{NMR}\left(126 \mathrm{MHz}, \mathrm{CDCl}_{3}\right) \delta 145.0,138.1,128.3,128.2,126.6,123.0,74.8,39.1,31.8,25.6,22.6,21.5,14.1$. HRMS (ESI ${ }^{+}$-Orbitrap): m/z calc. for: $\mathrm{C}_{13} \mathrm{H}_{19}: 175.1481\left[\mathrm{M}+\mathrm{H}-\mathrm{H}_{2} \mathrm{O}\right]^{+}$, found: 175.1486 . SFC $\left(\mathrm{Chiralpak} \mathrm{ID}-3, \mathrm{PrOH} / \mathrm{CO}{ }_{2}=5 / 95\right.$, flow rate $=1.2 \mathrm{~mL} / \mathrm{min}, 1=210 \mathrm{~nm}) \mathrm{tR}=1.72 \mathrm{~min}($ major, $(S)-3 \mathbf{a e}), 1.47 \mathrm{~min}(\operatorname{minor},(R)-3 \mathbf{a e})$. Specific rotation: $[\alpha]_{\mathrm{D}}{ }^{24}-17.2^{\circ}(\mathrm{c}$ $0.91, \mathrm{CHCl}_{3}$ ) for an enantiomerically enriched sample of 91:9 er. The absolute configuration was determined by comparison of the sign and the value of the optical rotation with that reported in literature for the opposite enantiomer $[\alpha]_{\mathrm{D}}^{20}+19.6^{\circ}\left(\mathrm{c} 0.32, \mathrm{CHCl}_{3}\right)$, $97: 3 .^{18}$

(S)-1-(Napthalen-2-yl)hexan-1-ol (3ag): Compound 3ag was prepared according to the general procedure with (S,S)-me-bipam, by reaction of hexan-1-ol $(0.25 \mathrm{mmol}, 31.4 \mathrm{uL})$, with 2-napthyl boronic acid $(0.75 \mathrm{mmol}, 129.0 \mathrm{mg})$ and was isolated by column chromatography (silica gel, petroleum ether to petroleum ether/ethyl acetate 85:15) to give a white, amorphous solid in $81 \%$ yield (46.0 mg). The analytical data are consistent with the ones previously reported. ${ }^{18}{ }^{1} \mathrm{H} \mathrm{NMR}\left(500 \mathrm{MHz}, \mathrm{CDCl}_{3}\right) \delta 7.92-7.66(\mathrm{~m}, 4 \mathrm{H})$, $7.52-7.42(\mathrm{~m}, 3 \mathrm{H}), 4.84(\mathrm{dd}, J=7.4,5.9 \mathrm{~Hz}, 1 \mathrm{H}), 1.94-1.75(\mathrm{~m}, 3 \mathrm{H}), 1.59-1.37(\mathrm{~m}, 1 \mathrm{H}), 1.37-1.29(\mathrm{~m}, 5 \mathrm{H}), 0.96-0.82(\mathrm{~m}$, $3 \mathrm{H}) .{ }^{13} \mathrm{C}\left\{{ }^{1} \mathrm{H}\right\} \mathrm{NMR}\left(126 \mathrm{MHz}, \mathrm{CDCl}_{3}\right) \delta 142.3,133.3,133.0,128.3,127.9,127.7,126.1,125.8,124.6,124.1,74.8,39.0,31.8,25.5$, 22.6, 14.1. HRMS (ESI+-Orbitrap): m/z calc. for: $\mathrm{C}_{16} \mathrm{H}_{19}$ : 211.1481 [M+H-H $\left.\mathrm{H}_{2}\right]^{+}$, found: 211.1488. SFC (Chiralpak ID-3, iPrOH/CO $=5 / 95$, flow rate $=1.2 \mathrm{~mL} / \mathrm{min}, 1=210 \mathrm{~nm}) \mathrm{tR}=4.05 \min ($ major, $(S)-3 \mathrm{ag}), 3.85 \mathrm{~min}(\operatorname{minor},(R)-3 \mathrm{ag})$. Specific rotation: $[\alpha]_{\mathrm{D}}{ }^{23}$ $-23.9^{\circ}\left(\mathrm{c} 1.0, \mathrm{CHCl}_{3}\right)$ for an enantiomerically enriched sample of 97:3 er. The absolute configuration was determined by comparison of the sign and the value of the optical rotation with that reported in literature for the opposite enantiomer $[\alpha]_{\mathrm{D}}^{20}+27.8^{\circ}(\mathrm{c} 1.43$, $\left.\mathrm{CHCl}_{3}\right), 98: 2 .^{18}$

(S)-1-(benzofuran-5-yl)hexan-1-ol (3ah): Compound 3ah was prepared according to the general procedure with $(S, S)$-me-bipam, by reaction of hexan-1-ol $(0.25 \mathrm{mmol}, 31.4 \mathrm{uL})$, with benzofuran-5-ylboronic acid $(0.75 \mathrm{mmol}, 121.5 \mathrm{mg})$ and was isolated by column chromatography (silica gel, petroleum ether to petroleum ether/ethyl acetate 85:15) to give a white, amorphous solid in 59\% yield (32.4 mg). ${ }^{1} \mathrm{H}$ NMR $\left(500 \mathrm{MHz}, \mathrm{CDCl}_{3}\right) \delta 7.63(\mathrm{~d}, J=2.2 \mathrm{~Hz}, 1 \mathrm{H}), 7.58(\mathrm{~d}, J=1.8 \mathrm{~Hz}, 1 \mathrm{H}), 7.47(\mathrm{~d}, J=8.4 \mathrm{~Hz}, 1 \mathrm{H}), 7.29(\mathrm{dd}, J=$ $8.5,1.8 \mathrm{~Hz}, 1 \mathrm{H}), 6.76(\mathrm{dd}, J=2.2,1.0 \mathrm{~Hz}, 1 \mathrm{H}), 4.76(\mathrm{dd}, J=7.5,6.0 \mathrm{~Hz}, 1 \mathrm{H}), 1.97-1.67(\mathrm{~m}, 3 \mathrm{H}), 1.49-1.36(\mathrm{~m}, 1 \mathrm{H}), 1.36-1.22$ (m, 5H), $0.94-0.83(\mathrm{~m}, 3 \mathrm{H}) .{ }^{13} \mathrm{C}\left\{{ }^{1} \mathrm{H}\right\}$ NMR $\left(126 \mathrm{MHz}, \mathrm{CDCl}_{3}\right) \delta 154.5,145.4,139.7,127.4,122.5,118.5,111.3,106.6,74.9,39.4$, 31.8, 25.6, 22.6, 14.1. HRMS (ESI+-Orbitrap): m/z calc. for: $\mathrm{C}_{14} \mathrm{H}_{17} \mathrm{O}: 201.1274$ [M+H-H$\left.{ }_{2} \mathrm{O}\right]^{+}$, found: 201.1275. SFC (Chiralpak IC3, $\mathrm{iPrOH} / \mathrm{CO}_{2}=5 / 95$, flow rate $=1.2 \mathrm{~mL} / \mathrm{min}, 1=210 \mathrm{~nm}$ ) $\mathrm{tR}=4.28 \mathrm{~min}$ (major, $\left.(S)-3 \mathbf{a h}\right), 3.86 \mathrm{~min}(\operatorname{minor},(R)-3 \mathbf{a h})$. Specific rotation: $[\alpha]_{\mathrm{D}}^{23}-24.0^{\circ}\left(\mathrm{c} 0.99, \mathrm{CHCl}_{3}\right)$ for an enantiomerically enriched sample of $96: 4 \mathrm{er}$. The absolute configuration was determined by analogy to compound $(S)-\mathbf{3 a a}$.

(S)-1-(4-(diphenylamino)phenyl)hexan-1-ol (3ai): Compound 3ai was prepared according to the general procedure with (S,S)-mebipam, by reaction of hexan-1-ol $(0.25 \mathrm{mmol}, 31.4 \mathrm{uL})$, with 4-(diphenyl-amino)phenyl boronic acid $(0.75 \mathrm{mmol}, 216.9 \mathrm{mg})$ and was isolated by column chromatography (silica gel, petroleum ether to petroleum ether/ethyl acetate 85:15) to give a red oil in $80 \%$ yield (69.2 mg). ${ }^{1} \mathrm{H}$ NMR (500 MHz, $\left.\mathrm{CDCl}_{3}\right) \delta 7.26-7.18(\mathrm{~m}, 6 \mathrm{H}), 7.10-7.04(\mathrm{~m}, 6 \mathrm{H}), 7.03-6.93(\mathrm{~m}, 2 \mathrm{H}), 4.65-4.58(\mathrm{~m}, 1 \mathrm{H})$, $1.89-1.76(\mathrm{~m}, 1 \mathrm{H}), 1.74(\mathrm{~d}, J=3.3 \mathrm{~Hz}, 1 \mathrm{H}), 1.73-1.64(\mathrm{~m}, 1 \mathrm{H}), 1.48-1.40(\mathrm{~m}, 1 \mathrm{H}), 1.39-1.24(\mathrm{~m}, 5 \mathrm{H}), 0.94-0.82(\mathrm{~m}, 3 \mathrm{H})$. ${ }^{13} \mathrm{C}\left\{{ }^{1} \mathrm{H}\right\} \mathrm{NMR}\left(126 \mathrm{MHz}, \mathrm{CDCl}_{3}\right) \delta 147.8,147.2,139.1,129.2,126.9,124.2,123.9,122.7,74.4,38.9,31.8,25.7,22.6,14.1 . \mathrm{HRMS}$ (ESI+-Orbitrap): m/z calc. for: $\mathrm{C}_{24} \mathrm{H}_{26} \mathrm{~N}$ : $328.2060\left[\mathrm{M}+\mathrm{H}-\mathrm{H}_{2} \mathrm{O}\right]^{+}$, found: 328.2066. SFC-MS $(\mathrm{Chiralpak} \mathrm{IG}-3, \mathrm{iPrOH} / \mathrm{CO} 2=15 / 85$, flow rate $=1.2 \mathrm{~mL} /$ rotation: $[\alpha]_{\mathrm{D}}^{23}-36.8^{\circ}\left(\mathrm{c} 0.95, \mathrm{CHCl}_{3}\right)$ for an enantiomerically enriched sample of $91: 9$ er. The absolute configuration was determined by analogy to compound $(S)$-3aa.

(S)-(4-methoxyphenyl)phenylmethanol (3fj): Compound 3fj was prepared according to the general procedure with $(S, S)$-me-bipam, by reaction of benzyl alcohol $(0.25 \mathrm{mmol}, 25.7 \mathrm{uL})$, with 4-methoxyphenyl boronic acid $(0.75 \mathrm{mmol}, 114.0 \mathrm{mg})$ and was isolated by column chromatography ( silica gel, petroleum ether to petroleum ether/ethyl acetate 85:15) to give a colourless oil in $78 \%$ yield (41.8 $\mathrm{mg})$. The analytical data are consistent with the ones previously reported. ${ }^{28}{ }^{1} \mathrm{H} \mathrm{NMR}\left(500 \mathrm{MHz}, \mathrm{CDCl}_{3}\right) \delta 7.41-7.31(\mathrm{~m}, 4 \mathrm{H}), 7.31$ $-7.21(\mathrm{~m}, 3 \mathrm{H}), 6.90-6.82(\mathrm{~m}, 2 \mathrm{H}), 5.82(\mathrm{~s}, 1 \mathrm{H}), 3.79(\mathrm{~s}, 3 \mathrm{H}), 2.16(\mathrm{~d}, J=8.4 \mathrm{~Hz}, 1 \mathrm{H}) .{ }^{13} \mathrm{C}\left\{{ }^{1} \mathrm{H}\right\} \mathrm{NMR}(126 \mathrm{MHz}, \mathrm{CDCl})_{3} \delta 159.1$, 144.0, 136.2, 128.5, 127.9, 127.5, 126.4, 113.9, 75.8, 55.3. HRMS (ESI+-Orbitrap): m/z calc. for: $\mathrm{C}_{14} \mathrm{H}_{13} \mathrm{O}: 197.0961\left[\mathrm{M}^{+} \mathrm{H}_{-} \mathrm{H}_{2} \mathrm{O}\right]^{+}$, 
found: 197.0966. SFC (Chiralpak IC-3, $\mathrm{iPrOH} / \mathrm{CO}_{2}=5 / 95$, flow rate $\left.=1.2 \mathrm{~mL} / \mathrm{min}, 1=210 \mathrm{~nm}\right) \mathrm{tR}=8.41 \mathrm{~min}(\mathrm{major},(S)-3 f j), 7.66$ $\min (\operatorname{minor},(R)-\mathbf{3 f j})$. Specific rotation: $[\alpha]_{\mathrm{D}}{ }^{23}-11.3^{\circ}\left(\mathrm{c} 0.99, \mathrm{CHCl}_{3}\right)$ for an enantiomerically enriched sample of 99:1 er. The absolute configuration was determined by comparison of the sign and the value of the optical rotation with that reported in literature $[\alpha]_{\mathrm{D}}^{22}$ $-14.8^{\circ}\left(\mathrm{c}_{0.81}, \mathrm{CHCl}_{3}\right), 96: 4 \mathrm{er}^{28}$

(S)-(3-chlorophenyl)phenylmethanol (3fk): Compound 3fk was prepared according to the general procedure with (S,S)-me-bipam, by reaction of benzyl alcohol $(0.25 \mathrm{mmol}, 25.7 \mathrm{uL})$, with 3-chlorophenyl boronic acid $(0.75 \mathrm{mmol}, 117.3 \mathrm{mg})$ and was isolated by column chromatography (silica gel, petroleum ether to petroleum ether/ethyl acetate $85: 15$ ) to give a colourless oil in $66 \%$ yield (36.4 $\mathrm{mg})$. The analytical data are consistent with the ones previously reported. ${ }^{28}{ }^{1} \mathrm{H} \mathrm{NMR}\left(500 \mathrm{MHz}, \mathrm{CDCl}_{3}\right) \delta 7.31(\mathrm{~d}, J=2.0 \mathrm{~Hz}, 1 \mathrm{H})$, $7.29-7.23(\mathrm{~m}, 4 \mathrm{H}), 7.19(\mathrm{ddd}, J=8.2,4.1,1.8 \mathrm{~Hz}, 1 \mathrm{H}), 7.17-7.07(\mathrm{~m}, 3 \mathrm{H}), 5.71(\mathrm{~d}, J=3.2 \mathrm{~Hz}, 1 \mathrm{H}), 2.13(\mathrm{~d}, J=3.4 \mathrm{~Hz}, 1 \mathrm{H})$. ${ }^{13} \mathrm{C}\left\{{ }^{1} \mathrm{H}\right\} \mathrm{NMR}\left(126 \mathrm{MHz}, \mathrm{CDCl}_{3}\right) \delta 145.7,143.2,134.4,129.8,128.7,128.0,127.7,126.6,126.6,124.6,75.7 . \mathrm{HRMS}_{\text {(ESI }}{ }^{+}-$Orbitrap): m/z calc. for: $\mathrm{C}_{13} \mathrm{H}_{10} \mathrm{Cl}: 201.0466\left[\mathrm{M}+\mathrm{H}-\mathrm{H}_{2} \mathrm{O}\right]^{+}$, found: 201.0469. SFC (Chiralpak IB-3, iPrOH/CO $\mathrm{CO}_{2}=5 / 95$, flow rate $=1.2 \mathrm{~mL} / \mathrm{min}$, $1=210 \mathrm{~nm}) \mathrm{tR}=7.38 \mathrm{~min}$ (major, $(S)-3 \mathrm{fk}), 6.76 \mathrm{~min}$ (minor, $(R)-3 f \mathbf{k})$. Specific rotation: $[\alpha]_{\mathrm{D}}^{23}+33.0^{\circ}\left(\mathrm{c} 1.0, \mathrm{CHCl}_{3}\right)$ for an enantiomerically enriched sample of $97:: 3$ er. The absolute configuration was determined by comparison of the sign and the value of the optical rotation with that reported in literature $[\alpha]_{\mathrm{D}}^{22}+33.1^{\circ}\left(\mathrm{c} 0.37, \mathrm{CHCl}_{3}\right), 98: 2 \mathrm{er}^{28}$

(R)-(3,5-Bis(trifluoromethyl)phenyl)phenylmethanol (3qa): Compound 3qa was prepared according to the general procedure with $(S, S)$-me-bipam, by reaction of 3,5-bis(trifluoromethyl)phenylmethanol ( $0.25 \mathrm{mmol}, 61.0 \mathrm{mg})$, with phenyl boronic acid ( $0.75 \mathrm{mmol}$, $91.4 \mathrm{mg}$ ) and was isolated by column chromatography (silica gel, petroleum ether to petroleum ether/ethyl acetate 85:15) to give a white, amorphous solid in $42 \%$ yield $(33.9 \mathrm{mg})$. The analytical data are consistent with the ones previously reported. ${ }^{45}{ }^{1} \mathrm{H}$ NMR $(500$ $\left.\mathrm{MHz}_{\mathrm{CDCl}}\right) \delta 7.87(\mathrm{~s}, 2 \mathrm{H}), 7.78(\mathrm{~s}, 1 \mathrm{H}), 7.43-7.31(\mathrm{~m}, 5 \mathrm{H}), 5.94(\mathrm{~d}, J=3.1 \mathrm{~Hz}, 1 \mathrm{H}), 2.37(\mathrm{~d}, J=3.2 \mathrm{~Hz}, 1 \mathrm{H}) .{ }^{13} \mathrm{C}\left\{{ }^{1} \mathrm{H}\right\} \mathrm{NMR}(126$ $\left.\mathrm{MHz} \mathrm{CDCl}_{3}\right) \delta 146.1,142.4,131.7(\mathrm{q}, J=33.3 \mathrm{~Hz}), 129.1,128.7,126.7,126.5(\mathrm{~m}), 123.3(\mathrm{~d}, J=272.7 \mathrm{~Hz}), 121.8-121.1(\mathrm{~m}), 75.3$. ${ }^{19} \mathrm{~F} \mathrm{NMR}\left(471 \mathrm{MHz}, \mathrm{CDCl}_{3}\right.$ ) $\delta$-62.79. HRMS (ESI ${ }^{+}$-Orbitrap): m/z calc. for: $\mathrm{C}_{15} \mathrm{H}_{9} \mathrm{~F}_{6}: 303.0603\left[\mathrm{M}+\mathrm{H}-\mathrm{H}_{2} \mathrm{O}\right]^{+}$, found: $303.0610 . \mathrm{SFC}^{2}$ (Chiralpak IB-3, $\mathrm{PrOH} / \mathrm{CO}_{2}=0.5 / 99.5$, flow rate $\left.=1.2 \mathrm{~mL} / \mathrm{min}, 1=210 \mathrm{~nm}\right) \mathrm{tR}=5.45$ min (major, $\left.(R)-3 q a\right), 4.98 \mathrm{~min}(\operatorname{minor},(S)-$ 3qa). Specific rotation: $[\alpha]_{\mathrm{D}}^{24}-34.1^{\circ}\left(\mathrm{c} 0.84, \mathrm{CHCl}_{3}\right)$ for an enantiomerically enriched sample of 96:4. The absolute configuration was determined by comparison of the sign and the value of the optical rotation with that reported in literature $[\alpha]_{\mathrm{D}}^{20}-38.6^{\mathrm{o}}(\mathrm{c} 0.80$, $\left.\mathrm{CHCl}_{3}\right), 90: 10$ er. $^{45}$

(R)-(4-bromophenyl)phenylmethanol (3ra): Compound 3ra was prepared according to the general procedure with $(S, S)$-me-bipam, by reaction of 4-bromophenylmethanol $(0.25 \mathrm{mmol}, 46.5 \mathrm{mg})$, with phenyl boronic acid $(0.75 \mathrm{mmol}, 91.4 \mathrm{mg})$ and was isolated by column chromatography (silica gel, petroleum ether to petroleum ether/ethyl acetate 85:15) to give a white, amorphous solid in $70 \%$ yield $(46.0 \mathrm{mg})$. The analytical data are consistent with the ones previously reported. ${ }^{28}{ }^{1} \mathrm{H} \mathrm{NMR}(500 \mathrm{MHz} \mathrm{CDCl} 3) \delta 7.49-7.43(\mathrm{~m}$, $2 \mathrm{H}), 7.38-7.31(\mathrm{~m}, 4 \mathrm{H}), 7.30-7.25(\mathrm{~m}, 3 \mathrm{H}), 5.81(\mathrm{~d}, J=3.3 \mathrm{~Hz}, 1 \mathrm{H}), 2.19(\mathrm{~d}, J=3.5 \mathrm{~Hz}, 1 \mathrm{H}) .{ }^{13} \mathrm{C}\left\{{ }^{1} \mathrm{H}\right\} \mathrm{NMR}\left(126 \mathrm{MHz}, \mathrm{CDCl}{ }_{3}\right)$ $\delta$ 143.4, 142.7, 131.6, 128.7, 128.2, 127.9, 126.5, 121.4, 75.7. HRMS (ESI+-Orbitrap): m/z calc. for: $\mathrm{C}_{13} \mathrm{H}_{10} \mathrm{Br}^{+} 244.9960$ [M+H$\left.\mathrm{H}_{2} \mathrm{O}\right]^{+}$, found: 244.9965. SFC (Chiralpak IC-3, $\mathrm{PrOH} / \mathrm{CO}_{2}=5 / 95$, flow rate $\left.=1.2 \mathrm{~mL} / \mathrm{min}, 1=210 \mathrm{~nm}\right) \mathrm{tR}=5.15 \mathrm{~min}(\mathrm{major},(R)-$ 3ra), $5.62 \min$ (minor, $(S)-3$ ra). Specific rotation: $[\alpha]_{\mathrm{D}}^{23}-15.5^{\circ}\left(\mathrm{c} 0.98, \mathrm{CHCl}_{3}\right)$ for an enantiomerically enriched sample of $97: 3$ er. The absolute configuration was determined by comparison of the sign and the value of the optical rotation with that reported in literature for the opposite enantiomer $[\alpha]_{\mathrm{D}}^{22}+18.2^{\circ}\left(\mathrm{c} 0.3, \mathrm{CHCl}_{3}\right), 96: 4 \mathrm{er}^{28}$

(R)-furan-3-yl(phenyl)methanol (3sa): Compound 3sa was prepared according to the general procedure with $(S, S)$-me-bipam, except that during the oxidation step the reaction was stirred for $16 \mathrm{~h}$, by reaction of furan-3-ylmethanol (0.25 mmol, $21.6 \mathrm{uL})$, with phenyl boronic acid $(0.75 \mathrm{mmol}, 91.4 \mathrm{mg}$ ) and was isolated by column chromatography (silica gel, petroleum ether to petroleum ether/ethyl acetate 85:15) to give a white, amorphous solid in $27 \%$ yield $(11.8 \mathrm{mg})$. The analytical data are consistent with the ones previously reported. ${ }^{2}{ }^{1} \mathrm{H}$ NR $\left(500 \mathrm{MHz}, \mathrm{CDCl}_{3}\right) \delta 7.45-7.34(\mathrm{~m}, 5 \mathrm{H}), 7.34-7.28(\mathrm{~m}, 2 \mathrm{H}), 6.34(\mathrm{~d}, \mathrm{~J}=1.8 \mathrm{~Hz}, 1 \mathrm{H}), 5.78(\mathrm{~s}, 1 \mathrm{H})$, $2.16(\mathrm{~s}, 1 \mathrm{H}) .{ }^{13} \mathrm{C}\left\{{ }^{1} \mathrm{H}\right\} \mathrm{NMR}\left(126 \mathrm{MHz}, \mathrm{CDCl}_{3}\right) \delta 143.5,143.0,139.8,128.9,128.6,127.9,126.4,109.2$, 69.5. HRMS (ESI $\left.{ }^{+}-O r b i t r a p\right)$ : $\mathrm{m} / \mathrm{z}$ calc. for: $\mathrm{C}_{11} \mathrm{H}_{9} \mathrm{O}: 157.0648\left[\mathrm{M}+\mathrm{H}-\mathrm{H}_{2} \mathrm{O}\right]^{+}$, found: $157.0651 . \mathrm{SFC}\left(\right.$ Chiralpak IC-3, $\mathrm{PrOH} / \mathrm{CO}_{2}=2.5 / 97.5$, flow rate $=1.2 \mathrm{~mL} / \mathrm{min}$, 
$1=210 \mathrm{~nm}) \mathrm{tR}=4.26 \mathrm{~min}($ major, $(R)-3 \mathrm{sa}), 4.82 \mathrm{~min}$ (minor, $(S)-3 \mathrm{sa})$. Specific rotation: $[\alpha]_{\mathrm{D}}{ }^{24}-3.4^{\circ}\left(\mathrm{c} 0.49, \mathrm{CHCl}_{3}\right)$ for an enantiomerically enriched sample of 99:1 er. The absolute configuration was determined by comparison of the sign and the value of the optical rotation with that reported in literature $[\alpha]_{\mathrm{D}}^{20}-2.7^{\circ}\left(\mathrm{c} 0.833 \mathrm{CHCl}_{3}\right), 97: 3 \mathrm{er}^{2}$

Competition experiments. In a nitrogen-filled glove box, a solution of Ru-1 and sodium acetate was prepared by allowing to stir $\left[\mathrm{Ru}(p \text {-cymene }) \mathrm{Cl}_{2}\right]_{2}(0.025$ equiv, $0.0063 \mathrm{mmol}, 3.8 \mathrm{mg}), \mathrm{rac}$-binap (0.05 equiv, $\left.0.013 \mathrm{mmol}, 7.8 \mathrm{mg}\right)$, and sodium acetate $(0.05$ equiv, $0.013 \mathrm{mmol}, 1.0 \mathrm{mg})$ in toluene $(1 \mathrm{~mL})$ at $80^{\circ} \mathrm{C}$ for $1 \mathrm{~h}$. Next, a $4 \mathrm{~mL}$ screw cap vial equipped with a stirring bar was charged with $N$-ethyl maleimide (31.3.4 mg, 1.0 equiv, $0.25 \mathrm{mmol}$ ), the solution of Ru-1 and sodium acetate, 1-hexanol (1 equiv, $0.25 \mathrm{mmol}$, $31.3 \mathrm{uL}$ ), and the competing alcohol (1 equiv, $0.25 \mathrm{mmol}$ ). The vial was then sealed with a Teflon-lined screw cap, removed from the glove box, placed in a pre-heated heating block at $80{ }^{\circ} \mathrm{C}$, and allowed to stir for $5 \mathrm{~h}$ at $800 \mathrm{rpm}$. After that, the reaction was cooled down, a known amount of dodecane was added and the reaction mixture was analysed by GC-FID. GC conversions were corrected for response factors for all compounds (See Supporting Information section III. Calibration Curves for GC Analysis).

\section{ASSOCIATED CONTENT}

\section{Supporting Information}

Experimental details and analytical data (pdf). This material is available free of charge via the Internet at http://pubs.acs.org

\section{AUTHOR INFORMATION}

\section{Corresponding Authors}

*E-mail: lichosyt@unistra.fr, dydio@unistra.fr

\section{Author Contributions}

All authors have given approval to the final version of the manuscript.

\section{ACKNOWLEDGMENT}

We acknowledge funding from the European Research Council (ERC StG no. 804106), the French National Research Agency (ANR IdEx, ANR LabEx „Chemistry of Complex Systems“, and the fellowships for BL and MA under contract 17-EURE-0016).

\section{REFERENCES}

(1) Seo, C. S. G.; Morris, R. H. Catalytic Homogeneous Asymmetric Hydrogenation: Successes and Opportunities. Organometallics 2019, 38 (1), 47-65. https://doi.org/10.1021/acs.organomet.8b00774.

(2) Salvi, L.; Kim, J. G.; Walsh, P. J. Practical Catalytic Asymmetric Synthesis of Diaryl-, Aryl Heteroaryl-, and Diheteroarylmethanols. J. Am. Chem. Soc. 2009, 131 (34), 12483-12493. https://doi.org/10.1021/ja9046747.

(3) Noyori, R. Facts Are the Enemy of Truth-Reflections on Serendipitous Discovery and Unforeseen Developments in Asymmetric Catalysis. Angew. Chem. Int. Ed. 2013, 52 (1), 79-92. https://doi.org/10.1002/anie.201205537.

(4) Noyori, R.; Ohkuma, T. Asymmetric Catalysis by Architectural and Functional Molecular Engineering: Practical Chemo - and Stereoselective Hydrogenation of Ketones. Angew. Chem. Int. Ed. 2001, 40 (1), 40-73. https://doi.org/10.1002/1521-3773(20010105)40:1<40::AIDANIE40>3.0.CO;2-5.

(5) Tian, P.; Dong, H.-Q.; Lin, G.-Q. Rhodium-Catalyzed Asymmetric Arylation. ACS Catal. 2012, 2 (1), $95-119$. https://doi.org/10.1021/cs200562n.

(6) Defieber, C.; Grützmacher, H.; Carreira, E. M. Chiral Olefins as Steering Ligands in Asymmetric Catalysis. Angew. Chem. Int. Ed. 2008, 47 (24), 4482-4502. https://doi.org/10.1002/anie.200703612.

(7) Mo, F.; Tabor, J. R.; Dong, G. Alcohols or Masked Alcohols as Directing Groups for C-H Bond Functionalization. Chem. Lett. 2014, 43 (3), 264-271. https://doi.org/10.1246/cl.131154. 

Nucleophiles: Reinventing Carbonyl Addition. Science 2016, 354 (6310), aah5133. https://doi.org/10.1126/science.aah5133. Lichosyt, D.; Zhang, Y.; Hurej, K.; Dydio, P. Dual-Catalytic Transition Metal Systems for Functionalization of Unreactive Sites of Molecules. Nat. Catal. 2019, 2 (2), 114-122. https://doi.org/10.1038/s41929-018-0207-1.

(10) Zbieg, J. R.; Yamaguchi, E.; McInturff, E. L.; Krische, M. J. Enantioselective C-H Crotylation of Primary Alcohols via Hydrohydroxyalkylation of Butadiene. Science 2012, 336 (6079), 324-327. https://doi.org/10.1126/science.1219274.

(11) Kim, S. W.; Zhang, W.; Krische, M. J. Catalytic Enantioselective Carbonyl Allylation and Propargylation via Alcohol-Mediated Hydrogen Transfer: Merging the Chemistry of Grignard and Sabatier. Acc. Chem. Res. 2017, 50 (9), 2371-2380. https://doi.org/10.1021/acs.accounts.7b00308.

(12) Guo, S.; Kumar, P. S.; Yang, M. Recent Advances of Oxidative Radical Cross-Coupling Reactions: Direct $\alpha-C\left(S p^{3}\right)$-H Bond Functionalization of Ethers and Alcohols. Adv. Synth. Catal. 2017, 359 (1), 2-25. https://doi.org/10.1002/adsc.201600467.

(13) Twilton, J.; Christensen, M.; DiRocco, D. A.; Ruck, R. T.; Davies, I. W.; MacMillan, D. W. C. Selective Hydrogen Atom Abstraction through Induced Bond Polarization: Direct $\alpha$-Arylation of Alcohols through Photoredox, HAT, and Nickel Catalysis. Angew. Chem. Int. Ed. 2018, 57 (19), 5369-5373. https://doi.org/10.1002/anie.201800749.

(14) Niu, L.; Liu, J.; Liang, X.-A.; Wang, S.; Lei, A. Visible Light-Induced Direct a C-H Functionalization of Alcohols. Nat. Commun. 2019, 10 (1). https://doi.org/10.1038/s41467-019-08413-9.

(15) Aoki, K.; Yonekura, K.; Ikeda, Y.; Ueno, R.; Shirakawa, E. Direct A-Arylation of Alcohols with Aryl Halides through a Radical Chain Mechanism. Adv. Synth. Catal. 2020, 362 (11), 2200-2204. https://doi.org/10.1002/adsc.202000216.

(16) He, T.; Yu, L.; Zhang, L.; Wang, L.; Wang, M. Direct C2-Alkylation of Azoles with Alcohols and Ethers through Dehydrogenative CrossCoupling under Metal-Free Conditions. Org. Lett. 2011, 13 (19), 5016-5019. https://doi.org/10.1021/ol201779n.

(17) Correia, C. A.; Yang, L.; Li, C.-J. Palladium-Catalyzed Minisci Reaction with Simple Alcohols. Org. Lett. 2011,13 (17), $4581-4583$. https://doi.org/10.1021/ol201774b.

(18) Casnati, A.; Lichosyt, D.; Lainer, B.; Veth, L.; Dydio, P. Multicatalytic Approach to One-Pot Stereoselective Synthesis of Secondary Benzylic Alcohols. Org. Lett. 2021, 23 (9), 3502-3506. https://doi.org/10.1021/acs.orglett.1c00939.

(19) Wang, D.; Astruc, D. The Golden Age of Transfer Hydrogenation. Chem. Rev. 2015, 115 (13), 6621-6686. https://doi.org/10.1021/acs.chemrev.5b00203.

(20) Hill, C. K.; Hartwig, J. F. Site-Selective Oxidation, Amination and Epimerization Reactions of Complex Polyols Enabled by Transfer Hydrogenation. Nat. Chem. 2017, 9 (12), 1213-1221. https://doi.org/10.1038/nchem.2835.

(21) Martínez, S.; Veth, L.; Lainer, B.; Dydio, P. Challenges and Opportunities in Multicatalysis. ACS Catal. 2021, 3891-3915. https://doi.org/10.1021/acscatal.0c05725.

(22) Sancheti, S. P.; Urvashi; Shah, M. P.; Patil, N. T. Ternary Catalysis: A Stepping Stone toward Multicatalysis. ACS Catal. 2020, 10 (5), 3462-3489. https://doi.org/10.1021/acscatal.9b04000.

(23) Lohr, T. L.; Marks, T. J. Orthogonal Tandem Catalysis. Nat. Chem. 2015, 7 (6), 477-482. https://doi.org/10.1038/nchem.2262.

(24) Patil, N. T.; Shinde, V. S.; Gajula, B. A One-Pot Catalysis: The Strategic Classification with Some Recent Examples. Org Biomol Chem 2012, 10 (2), 211-224. https://doi.org/10.1039/C1OB06432K.

(25) Fogg, D. E.; dos Santos, E. N. Tandem Catalysis: A Taxonomy and Illustrative Review. Coord. Chem. Rev. 2004, 248 (21-24), 2365-2379. https://doi.org/10.1016/j.ccr.2004.05.012.

(26) Romiti, F.; del Pozo, J.; Paioti, P. H. S.; Gonsales, S. A.; Li, X.; Hartrampf, F. W. W.; Hoveyda, A. H. Different Strategies for Designing Dual-Catalytic Enantioselective Processes: From Fully Cooperative to Non-Cooperative Systems. J. Am. Chem. Soc. 2019, 141 (45), 1795217961. https://doi.org/10.1021/jacs.9b05464.

(27) Pellissier, H. Recent Developments in Enantioselective Multicatalyzed Tandem Reactions. Adv. Synth. Catal. 2020, 362 (12), 2289-2325. https://doi.org/10.1002/adsc.202000210.

(28) Yamamoto, Y.; Kurihara, K.; Miyaura, N. Me-Bipam for Enantioselective Ruthenium(II)-Catalyzed Arylation of Aldehydes with Arylboronic Acids. Angew. Chem. Int. Ed. 2009, 48 (24), 4414-4416. https://doi.org/10.1002/anie.200901395.

(29) Yamamoto, Y.; Shirai, T.; Watanabe, M.; Kurihara, K.; Miyaura, N. Ru/Me-BIPAM-Catalyzed Asymmetric Addition of Arylboronic Acids to Aliphatic Aldehydes and $\alpha$-Ketoesters. Molecules 2011, 16 (6), 5020-5034. https://doi.org/10.3390/molecules 16065020. 

381-390. https://doi.org/10.1021/ic701773a.

(31) Huang, Z.; Wang, Y.; Leng, X.; Huang, Z. An Amine-Assisted Ionic Monohydride Mechanism Enables Selective Alkyne Cis -Semihydrogenation with Ethanol: From Elementary Steps to Catalysis. J. Am. Chem. Soc. 2021, 143 (12), $4824-4836$. https://doi.org/10.1021/jacs.1c01472.

(32) Hayashi, Y. Pot Economy and One-Pot Synthesis. Chem. Sci. 2016, 7 (2), 866-880. https://doi.org/10.1039/C5SC02913A.

(33) Ambrosini, L. M.; Lambert, T. H. Multicatalysis: Advancing Synthetic Efficiency and Inspiring Discovery. ChemCatChem 2010, 2 (11), 1373-1380. https://doi.org/10.1002/cctc.200900323.

(34) Ramachary, D. B.; Jain, S. Sequential One-Pot Combination of Multi-Component and Multi-Catalysis Cascade Reactions: An Emerging Technology in Organic Synthesis. Org Biomol Chem 2011, 9 (5), 1277-1300. https://doi.org/10.1039/C0OB00611D.

(35) Yadav, R. N.; Srivastava, A. K.; Banik, B. K. One-Pot Strategy: A Highly Economical Tool in Organic Synthesis and Medicinal Chemistry. In Green Approaches in Medicinal Chemistry for Sustainable Drug Design; Elsevier, 2020; pp 353-425. https://doi.org/10.1016/B978-012-817592-7.00010-1.

(36) Matsunaga, S.; Das, J.; Roels, J.; Vogl, E. M.; Yamamoto, N.; Iida, T.; Yamaguchi, K.; Shibasaki, M. Catalytic Enantioselective $m$ Eso Epoxide Ring Opening Reaction with Phenolic Oxygen Nucleophile Promoted by Gallium Heterobimetallic Multifunctional Complexes . $J$. Am. Chem. Soc. 2000, 122 (10), 2252-2260. https://doi.org/10.1021/ja993650f.

(37) Kurihara, K.; Sugishita, N.; Oshita, K.; Piao, D.; Yamamoto, Y.; Miyaura, N. Enantioselective 1,4-Addition of Arylboronic Acids to $\alpha, \beta-$ Unsaturated Carbonyl Compounds Catalyzed by Rhodium(I)-Chiral Phosphoramidite Complexes. J. Organomet. Chem. 2007, 692 (1-3), 428-435. https://doi.org/10.1016/j.jorganchem.2006.04.042.

(38) Lo, V. K.-Y.; Guo, Z.; Choi, M. K.-W.; Yu, W.-Y.; Huang, J.-S.; Che, C.-M. Highly Selective Intramolecular Carbene Insertion into Primary C-H Bond of $\alpha$-Diazoacetamides Mediated by a ( $p$-Cymene)Ruthenium(II) Carboxylate Complex. J. Am. Chem. Soc. 2012, 134 (18), 7588-7591. https://doi.org/10.1021/ja3006989.

(39) Allegretti, P. A.; Ferreira, E. M. Vicinal Bisheterocyclizations of Alkynes via Nucleophilic Interception of a Catalytic Platinum Carbene. J. Am. Chem. Soc. 2013, 135 (46), 17266-17269. https://doi.org/10.1021/ja408957a.

(40) Harris, M. R.; Konev, M. O.; Jarvo, E. R. Enantiospecific Intramolecular Heck Reactions of Secondary Benzylic Ethers. J. Am. Chem. Soc. 2014, 136 (22), 7825-7828. https://doi.org/10.1021/ja5026485.

(41) Hayes, A. M.; Morris, D. J.; Clarkson, G. J.; Wills, M. A Class of Ruthenium(II) Catalyst for Asymmetric Transfer Hydrogenations of Ketones. J. Am. Chem. Soc. 2005, 127 (20), 7318-7319. https://doi.org/10.1021/ja051486s.

(42) Lovinger, G. J.; Morken, J. P. Ni-Catalyzed Enantioselective Conjunctive Coupling with C(Sp ${ }^{3}$ ) Electrophiles: A Radical-Ionic Mechanistic Dichotomy. J. Am. Chem. Soc. 2017, 139 (48), 17293-17296. https://doi.org/10.1021/jacs.7b10519.

(43) Cao, W.; Tan, D.; Lee, R.; Tan, C.-H. Enantioselective 1,2-Anionotropic Rearrangement of Acylsilane through a Bisguanidinium Silicate Ion Pair. J. Am. Chem. Soc. 2018, 140 (5), 1952-1955. https://doi.org/10.1021/jacs.7b13056.

(44) Williams, D. R.; Heidebrecht, R. W. Total Synthesis of (+)-4,5-Deoxyneodolabelline. J. Am. Chem. Soc. 2003,125 (7), $1843-1850$. https://doi.org/10.1021/ja0279803.

(45) Barsamian, A. L.; Wu, Z.; Blakemore, P. R. Enantioselective Synthesis of $\alpha$-Phenyl- and $\alpha$-(Dimethylphenylsilyl)Alkylboronic Esters by Ligand Mediated Stereoinductive Reagent-Controlled Homologation Using Configurationally Labile Carbenoids. Org. Biomol. Chem. 2015, 13 (12), 3781-3786. https://doi.org/10.1039/C5OB00159E. 